\title{
Epidemiology of Prostate Cancer
}

\author{
Prashanth Rawla
}

\begin{abstract}
Prostate cancer is the second most frequent cancer diagnosis made in men and the fifth leading cause of death worldwide. Prostate cancer may be asymptomatic at the early stage and often has an indolent course that may require only active surveillance. Based on GLOBOCAN 2018 estimates, 1,276,106 new cases of prostate cancer were reported worldwide in 2018, with higher prevalence in the developed countries. Differences in the incidence rates worldwide reflect differences in the use of diagnostic testing. Prostate cancer incidence and mortality rates are strongly related to the age with the highest incidence being seen in elderly men ( $>65$ years of age). African-American men have the highest incidence rates and more aggressive type of prostate cancer compared to White men. There is no evidence yet on how to prevent prostate cancer; however, it is possible to lower the risk by limiting high-fat foods, increasing the intake of vegetables and fruits and performing more exercise. Screening is highly recommended at age 45 for men with familial history and AfricanAmerican men. Up-to-date statistics on prostate cancer occurrence and outcomes along with a better understanding of the etiology and causative risk factors are essential for the primary prevention of this disease.
\end{abstract}

Keywords: Prostate cancer; Epidemiology; Incidence; Mortality; Trends; Survival; Etiology; Risk factors; Prevention

\section{Introduction}

Prostate cancer is the second most frequent malignancy (after lung cancer) in men worldwide, counting 1,276,106 new cases and causing 358,989 deaths (3.8\% of all deaths caused by cancer in men) in 2018 [1,2]. The incidence and mortality of prostate cancer worldwide correlate with increasing age with the average age at the time of diagnosis being 66 years. Of note, for African-American men, the incidence rates are higher when compared to the White men, with 158.3 new cases diagnosed per 100,000 men and their mortality is approximately twice as White men [3]. Reasons for this disparity have been hypothesized to differences in social, environmental and ge-

Manuscript submitted February 20, 2019, accepted March 15, 2019

Hospitalist, Department of Internal Medicine, SOVAH Health, Martinsville, VA 24112, USA. Email: rawlap@gmail.com

doi: https://doi.org/10.14740/wjon1191 netic factors. Although 2,293,818 new cases are estimated until 2040, a small variation in mortality will be observed (an increase of $1.05 \%$ ) [4].

Prostate cancer may be asymptomatic at the early stage and often has an indolent course, and may require minimal or even no treatment. However, the most frequent complaint is difficulty with urination, increased frequency, and nocturia, all symptoms that may also arise from prostatic hypertrophy. More advanced stage of the disease may present with urinary retention and back pain, as axis skeleton is the most common site of bony metastatic disease.

Many prostate cancers are detected on the basis of elevated plasmatic levels of prostate-specific antigen (PSA $>4$ $\mathrm{ng} / \mathrm{mL}$ ), a glycoprotein normally expressed by prostate tissue. However, because men without cancer have also been found with elevated PSA, a tissue biopsy is the standard of care to confirm cancer's presence.

Diet and physical activity play an important role in prostate cancer development and progression. Dietary factors are mainly associated with the observed worldwide and ethnic differences in the incidence rates of prostate cancer [5-9].

Most studies are devoted not only into identifying genes involved in the inherited form of prostate cancer but also the mutations occurring in the acquired form. Therefore, a detailed analysis of prostate cancer epidemiology and evaluation of risk factors can help to understand the connection between genetic mutations and the role of the environment in triggering these mutations and/or favoring tumor progression. Increased understanding of the etiology and causative risk factors of prostate cancer will provide ways to identify at-risk males and support the development of effective screening and prevention methods.

\section{Epidemiology}

Based on GLOBOCAN 2018 estimates, we have evaluated worldwide prostate cancer incidence and mortality rates, as well as analyzed incidence and mortality, temporal trends and survival rates.

\section{Incidence}

The incidence rate of prostate cancer varies across the regions and populations (Fig. 1) [2]. In 2018, 1,276,106 new cases of prostate cancer were registered worldwide, representing $7.1 \%$ of all cancers in men [1]. Prostate cancer incidence rates are highly variable worldwide. The age-standardized rate (ASR) 


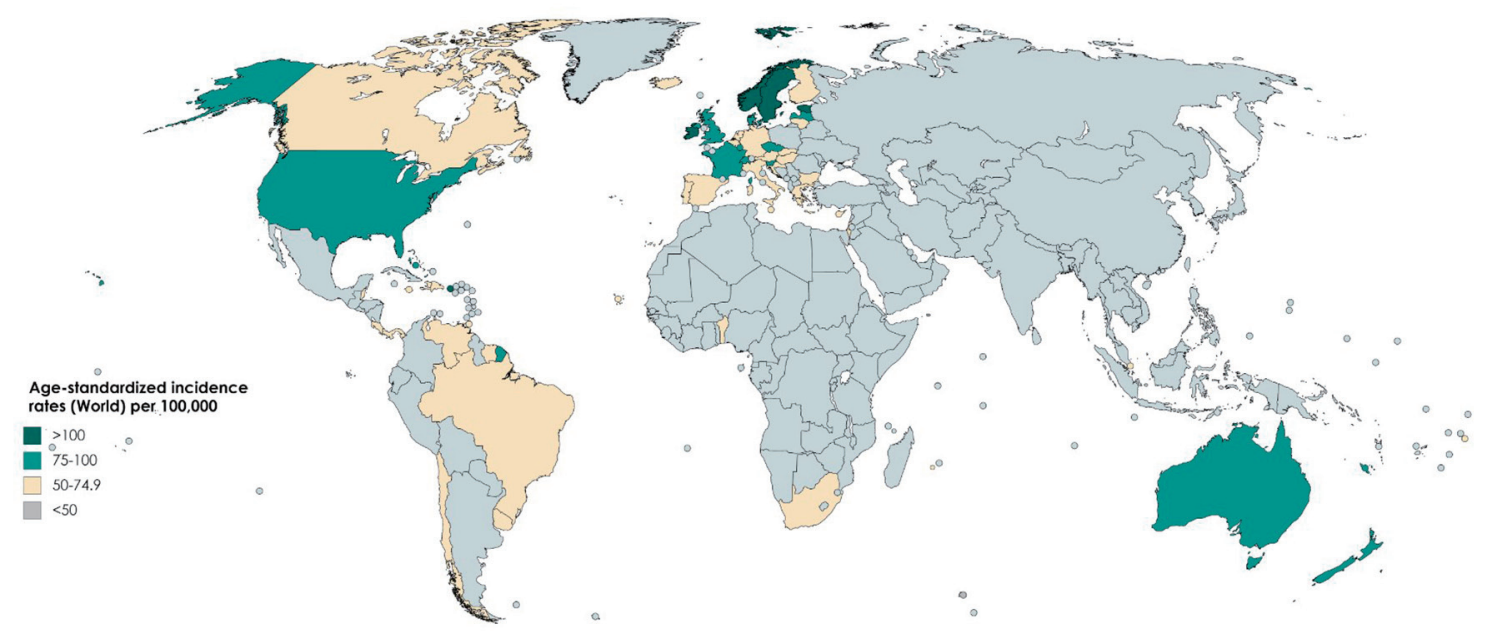

Figure 1. Map showing estimated age-standardized incidence rates for prostate cancer worldwide in 2018, in males including all ages. Created with mapchart.net. Data obtained from Globocan 2018 [2].

was highest in Oceania (79.1 per 100,000 people) and North America (73.7), followed by Europe (62.1). Conversely, Africa and Asia have incidence rates that are lower than those from developed countries (26.6 and 11.5, respectively) [2]. Differences in incidence rates were 190 -fold between the populations at the highest rate (France, Guadeloupe, 189.1), and the populations with the lowest rate (Bhutan, 1.0).

Prostate cancer incidence increases with age [2]. Although only 1 in 350 men under the age of 50 years will be diagnosed with prostate cancer [10], the incidence rate increases up to 1 in every 52 men for ages 50 to 59 years. The incidence rate is nearly $60 \%$ in men over the age of 65 years [11].

The reason for these differences among the countries is not entirely clear. The worldwide variations in prostate cancer incidence might be attributed to PSA testing [12]. For example, in Europe, prostate cancer is the most frequently diagnosed cancer among men, accounting for $24 \%$ of all new cancers in 2018, with around 450,000 new prostate cancer cases estimated in 2018 [13]. While in the USA, prostate cancer is the second most common cancer accounting for $9.5 \%$ of all new cancer cases $(164,690$ new cases of prostate cancer) registered in 2018 [14]. According to recently conducted research studies, around $20-40 \%$ of the prostate cancer cases in the USA and Europe could be due to overdiagnosis through extensive PSA testing $[12,15,16]$.

Research has shown that African-American men have the highest incidence of prostate cancer worldwide and more likely to develop disease earlier in life when compared to other racial and ethnic groups [17]. This is reflected in data not only for African-American men, but also for Caribbeans, and Black men in Europe, suggesting that they possess a common genetic background more prone to the development of the cancer. Of note, $\mathrm{Chu}$ et al [18] reported that incidence rates of prostate cancer were as much as 40 times higher among African-American men than those in Africa. These differences suggest that environmental factors also play an important role in the etiology of the prostate cancer and variations in incidence may be due to underdiagnosis, differences in the screening methods and disparities in healthcare access.

\section{Mortality}

International mortality rates for prostate cancer vary considerably worldwide (Fig. 2) [2]. In 2018, the highest mortality rates were recorded in Central America (10.7 per 100,000 people), followed by Australia and New Zealand (10.2) and Western Europe (10.1) [2]. The lowest rate was reported in the countries of Asia (South-Central, 3.3; Eastern, 4.7 and South-Eastern, 5.4) and Northern Africa (5.8) (Fig. 3) [2]. One-third of the deaths for prostate cancer occurred in Asia (33.0\%, 118,427 of deaths), followed by Europe (29.9\%, 107,315 of deaths). The mortality rate of prostate cancer rises with age, and almost $55 \%$ of all deaths occur after 65 years of age [2].

US Preventive Task Force (USPSTF, 2018) has reported that there is a potential benefit of decreasing deaths from prostate cancer in men aged 55 - 69 years with PSA screening [19]. However, for men above 70 years of age for all races, the data are less convincing [20].

African-American men have the highest prostate cancer incidence and mortality rates. This suggests not only that African-American men may possess some specific genes that are more susceptible to mutations in prostate cancer, but mainly that these mutations are associated with a more aggressive type of cancer. However, a study conducted by Oliver in 2007 [21] reported that African-American men were less likely to identify early symptoms of prostate cancer correctly than Caucasian men.

\section{Trends}

Temporal trends of prostate cancer incidence and mortality varied significantly internationally during the past years, and they seem tightly correlated to the adoption of PSA testing for 


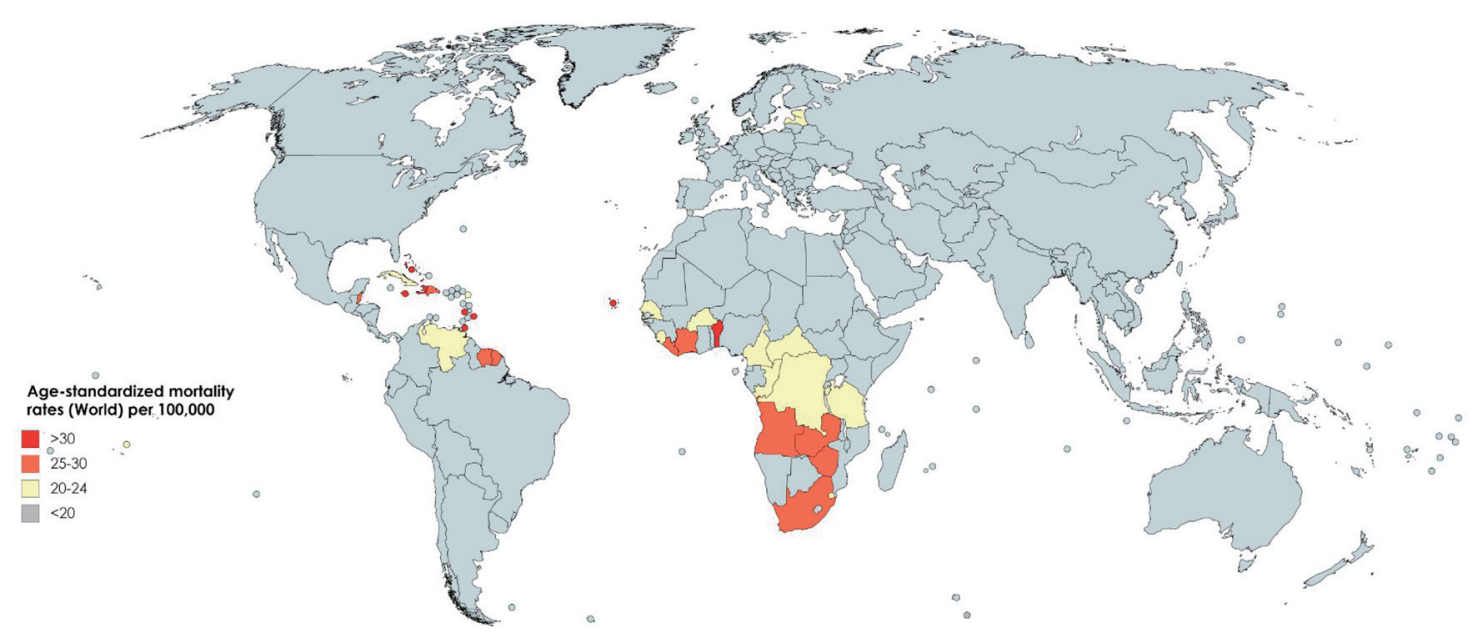

Figure 2. Map showing estimated age-standardized mortality rates for prostate cancer worldwide in 2018 , in males including all ages. Created with mapchart.net. Data obtained from Globocan 2018 [2].

early detection of the disease especially in Western countries [22].

Incidence rates in the USA, Australia, and Canada have seen an increase between the 1980s and 1990s but now decreasing because of rapid dissemination of PSA testing [22, 23], while rates in European countries continue to slightly increase because of increased understanding of PSA screening and gradual adoption of PSA testing, but also other factors may be involved, such as exposure to ultraviolet radiation and diet [24].

Interestingly, a trend towards an increase of prostate cancer incidence worldwide with $1,017,712$ new cases $(+79.7 \%$ overall change) up to 2040 is estimated (Table 1) [4]. The highest incidence of prostate cancer will be registered in Af- rica ( $+120.6 \%)$, followed by Latin America and the Caribbean $(+101.1 \%)$ and Asia (100.9\%). On the contrary, the lowest incidence will be registered in Europe $(+30.1 \%)$. This increase in the incidence rates appears to be related to an increased life expectancy. Increasing incidence rate trends in developing countries is likely due to improved access to medical care as well as increased documentation and reporting of cases. Finally, the fact that incidence rates are increasing in those regions where PSA testing is not routinely used suggests that this phenomenon reflects westernization of the lifestyle including obesity, physical inactivity and dietary factors [25].

Prostate cancer mortality rates in most western countries including North America as well as in Western and North Europe have been steadily declining $[22,25]$. Although the

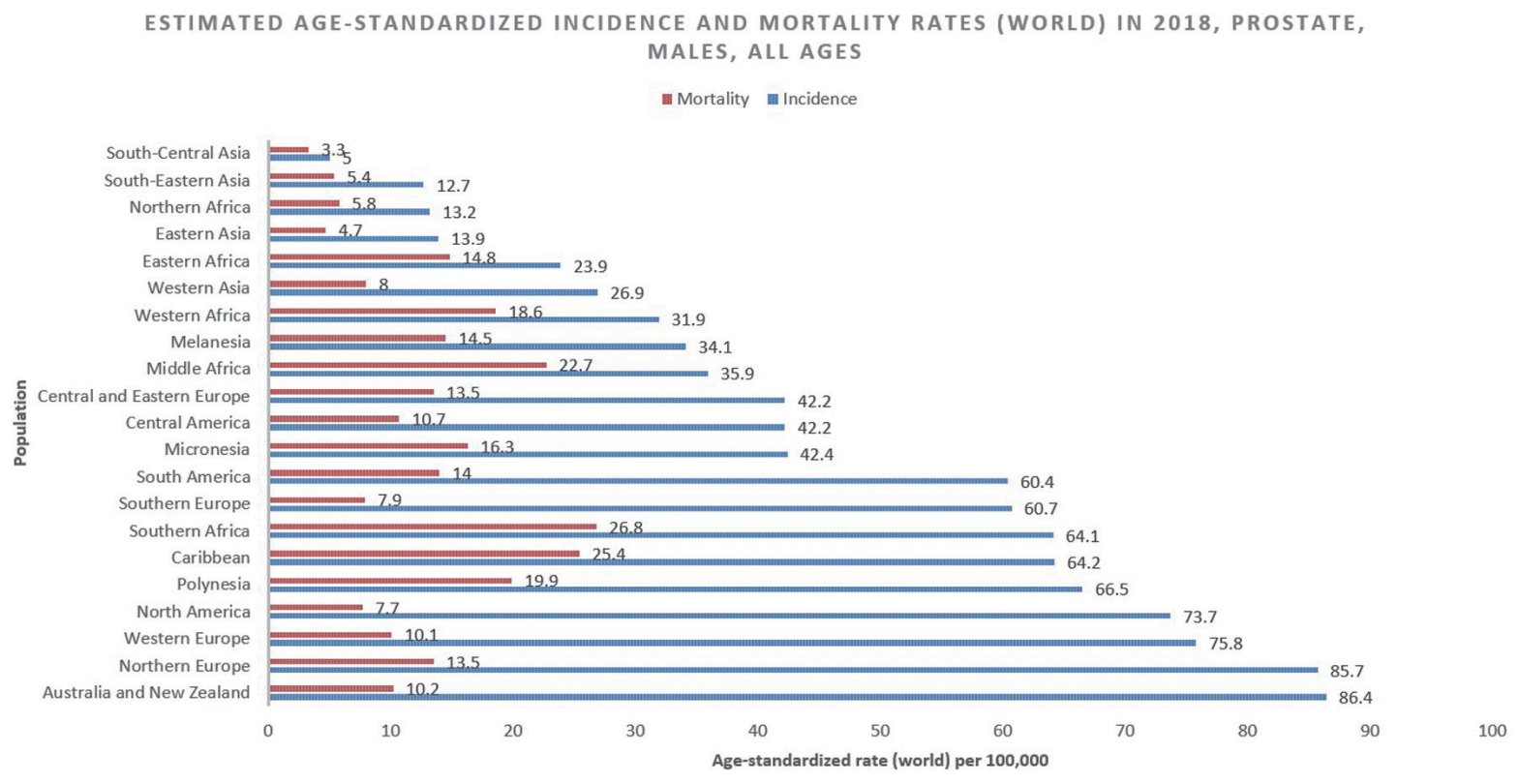

Figure 3. Bar chart showing estimated age-standardized incidence and mortality rates (world) in 2018, prostate, males, all ages. Data obtained from Globocan 2018 [2]. 
Table 1. Estimated Number of Incident Cases From 2018 to 2040, Prostate Cancer, Males, All Ages

\begin{tabular}{|c|c|c|c|c|c|c|}
\hline & & 2018 & & & 2040 & \\
\hline & & Number & Number & Demographic change & Change in risk & Overall change \\
\hline Africa & Males (APC 0\%) & 80,971 & 178,634 & $97,663(+120.6 \%)$ & $97,663(+120.6 \%)$ & $97,663(+120.6 \%)$ \\
\hline North America & Males (APC 0\%) & 234,278 & 312,901 & $78,623(+33.6 \%)$ & $78,623(+33.6 \%)$ & $78,623(+33.6 \%)$ \\
\hline Europe & Males (APC 0\%) & 449,761 & 585,134 & $135,373(+30.1 \%)$ & $135,373(+30.1 \%)$ & $135,373(+30.1 \%)$ \\
\hline
\end{tabular}

Data obtained from Globocan 2018 [4].

reasons are not clear, it may reflect both early detection and improved treatment [26-28]. However, in the USA, a recent randomized controlled trial failed to demonstrate benefits of PSA testing in decreasing prostate cancer deaths, although another research study done in Europe showed benefits of PSA testing $[29,30]$. When ethnicity-specific trends were analyzed, it was observed that the decline in mortality in African-American men was greater than that in White men between 2001 and 2015 (Fig. 4) [11, 20]. Negoita et al documented that improved and newer modalities of detection and treatments and improved treatment of resistant and metastatic prostate cancer may justify this trend [20].

From 2018 to 2040, it is estimated that mortality will double with 379,005 deaths worldwide [4]. The highest mortality rate is estimated to be in Africa $(+124.4 \%)$, followed by Asia (116.7\%), while the lowest incidence will be registered in Europe $(+58.3 \%)$ (Table 2$)$ [4]. The above finding is not surprising due to the limited resources for screening and detection of prostate cancer which increases the odds of it being detected during the late stages. Furthermore, considering that medical care and assistance is not widely accessible in developing countries, this may provide a possible explanation for the high mortality despite the lower incidence.

\section{Survival}

Although prostate cancer incidence rates are high, most prostate cancer cases are detected when the cancer is confined to within the prostate. The 5-year survival rate in the USA for men diagnosed with prostate cancer is around 98\% [11]. The data from the Eurocare project (EUROCARE-5) of patients diagnosed with prostate cancer from 2003 to 2007 showed that 5 -year survival rates were $83 \%$ [13]. Survival varied from $76 \%$ in Eastern countries to $88 \%$ in Southern and Central European countries. Moreover, survival has increased over time in all over Europe with the greatest improvement being observed in the Eastern European countries [31].

Despite in the last decades, science has made so much progress to unveil molecular mechanisms and risk factors involved in the prostate cancer, it still is the second leading cause of cancer mortality among males in the USA [32]. Finally, the general idea for all types of cancers is that the earlier they are caught, the earlier they can be successfully treated remaining

Prostate Cancer

Recent Trends in U.S. Mortality Rates, 2000-2015

By Race/Ethnicity
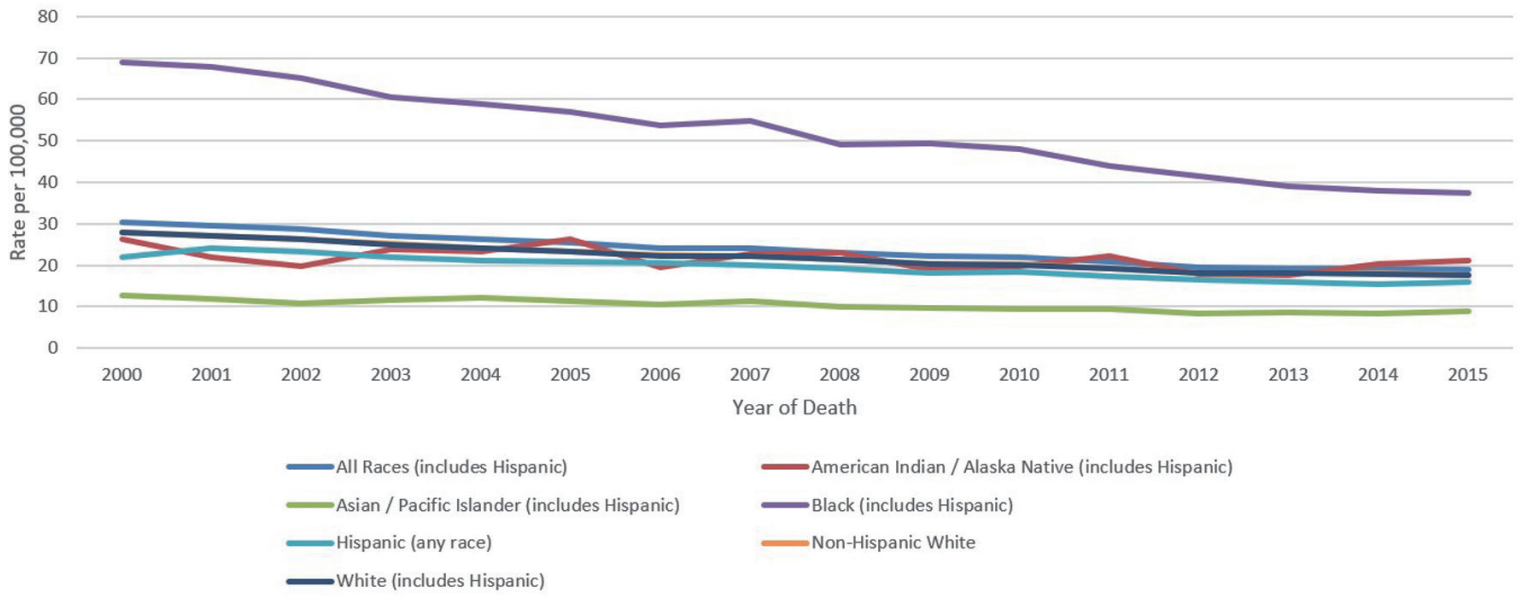

Figure 4. Recent trends of prostate cancer mortality rates in USA in 2000 - 2015 by race/ethnicity. Data source: US Mortality Files, National Center for Health Statistics, CDC [11]. 
Table 2. Estimated Number of Deaths From 2018 to 2040, Prostate Cancer, Males, All Ages

\begin{tabular}{|c|c|c|c|c|c|c|}
\hline & \multirow{2}{*}{$\begin{array}{l}2018 \\
\text { Number }\end{array}$} & \multicolumn{4}{|c|}{2040} \\
\hline & & & Number & Demographic change & Change in risk & Overall change \\
\hline Africa & Males (APC 0\%) & 42,298 & 94,909 & $52,611(+124.4 \%)$ & $52,611(+124.4 \%)$ & $52,611(+124.4 \%)$ \\
\hline North America & Males (APC 0\%) & 32,686 & 65,766 & $33,080(+101.2 \%)$ & $33,080(+101.2 \%)$ & $33,080(+101.2 \%)$ \\
\hline Europe & Males (APC $0 \%$ ) & 107,315 & 169,865 & $62,550(+58.3 \%)$ & $62,550(+58.3 \%)$ & $62,550(+58.3 \%)$ \\
\hline
\end{tabular}

Data obtained from Globocan 2018 [4].

the patients disease-free. However, because the majority of prostate cancer have a slow and often indolent course (defined as "low-risk" tumor), men can avoid immediate treatment (and prospective side effects) while safely undergoing active surveillance or watchful waiting.

\section{Etiology and Risk Factors}

The etiology of prostate cancer is the subject of numerous studies and remains largely unknown compared to other common cancers. The well-established prostate cancer risk factors are advanced age, ethnicity, genetic factors and family history [33-35]. Other factors positively associated with prostate cancer include diet (increased consumption of saturated animal fat and red meat, lower intake of fruits, vegetables, vitamins, and coffee), obesity and physical inactivity, inflammation, hyperglycemia, infections, and environmental exposure to chemicals or ionizing radiation [34, 36-40].

\section{Age}

Prostate cancer is the most commonly diagnosed malignancy among elderly males [1]. Indeed, an increasing number of senior men are diagnosed with prostate cancer due to increasing life expectancy and the increased use of PSA screening. It was observed that the risk increases especially after 50 years of age in White men who have no family history of the prostate cancer, and after 40 years of age in Black men or men with a familial history of prostate cancer [14].

Scardino reported that almost $30 \%$ of men over 50 years of age, who died for causes other than prostate cancer, were found with histological evidence of prostate cancer at the moment of autopsy [41]. Indeed, due to its indolent course, elderly men who have concurrent severe co-morbid disease during their lifetimes are more likely to die from other related health conditions or other diseases rather than from prostate cancer.

\section{Ethnicity}

Prevalence of prostate cancer highly varies among different racial groups. In the USA, the lowest incidence is observed in American Indian/Alaska (46.9) Native and Asian/Pacific Is- lander (52.4), followed by White (93.9). The highest incidence rate is seen in African-American men (157.6) [11].

This vast disparity has been associated with both socioeconomic conditions and biologic factors [42]. For instance, it is believed that African Americans receive lower-quality healthcare and consequently, they are also less likely to undergo PSA screening [43]. Notably, significantly higher PSA levels were seen in Black men, with or without prostate cancer when compared to White men [44, 45].

Several studies proposed that genetic predisposition might play a role. African-American men have the more common chromosome $8 \mathrm{q} 24$ variants, which have been shown to be associated with increased prostate cancer risk [46-49]. Some research studies have also demonstrated that African Americans have a high rate of variations in genes that suppress tumors such as EphB2 [50] or that regulate cell apoptosis such as BCL2 [51]. Furthermore, African-American men display a more aggressive form of the disease, which has also been associated with genetic and biologic differences, although lack of adequate screening and delayed presentation was not excluded too [42].

\section{Family history and genetic factors}

It is estimated that about $20 \%$ of patients with prostate cancer report a family history, which may develop not only because of shared genes but also for a similar pattern of exposure to certain environmental carcinogens and common lifestyle habits $[52,53]$. Several studies reported that inherited genetic background is associated with increased risk for prostate cancer, contributing to about $5 \%$ of disease risks $[54,55]$. Particularly, this risk is increased by several folds when high-penetrance genetic "risk" alleles are inherited, conversely to more common low-penetrance loci that increase the risk only modestly.

Gene linkage studies reveal major susceptibility loci for prostate carcinoma on genes in seven different loci. Chromosome 1q24-25 that is referred as HPC1 gene encodes the enzyme ribonuclease L (RNASEL) [56], which is involved in the innate immune defense mechanisms and the interferon (IFN)-mediated signaling [57]. It plays an important role in reducing antiviral activity and the regulation of apoptotic cell death [58]. Of note, analysis of human prostate cancer samples from patients with RNASEL mutations showed the presence of retrovirus unveiling the importance of antiviral defenses to prostate cancer develop- 
ment [59]. Moreover, detection of retroviral infections in some cases of prostate cancer also showed the potential connection of chronic retroviral infection and consequent tissue inflammation with cancer initiation [60,61]. Another HPC gene (HPC2/ ELAC2) was identified on chromosome $17 \mathrm{p} 11$ and encodes a protein with poorly understood function [62], ELAC2, which is involved in prostate cancer development by binding SMAD2 that up-regulate proliferation through activation of TGF-beta signaling pathway [63]. The third identified HPC gene is macrophage scavenger receptor 1 (MSR1), which resides on chromosome 8p22 [64]. However, considering the low penetrance of this allele, several studies failed to confirm its association with HPC $[65,66]$. Additionally, a subset of HPC was found to occur in men with $B R C A 1$ and 2 mutations that showed a clinically aggressive form of prostate cancer [67]. Moreover, $B R C A 2$ mutations were correlated with a higher incidence of prostate cancer, and PALB2, BRCA2-interacting protein, was involved in familial prostate cancer [68].

The $\mathrm{X}$ chromosome is also believed to have a role in prostate cancer inheritance, because it contains the androgen receptor (AR) and because small deletions in Xq26.3-q27.3 region were noted in sporadic and hereditary forms of prostate cancer $[69,70]$. More recent studies in 301 hereditary prostate cancer affected families defined a number of other loci that may contribute to hereditary prostate cancer [71].

\section{Diet}

Dietary factors may play an essential role in the development of prostate cancer as evidenced by several studies on immigrants moving from developing countries (low-risk areas) to industrialized countries (higher risk), that showed how the change to a "westernized" lifestyle induced a shift towards an increased prostate cancer incidence. For example, Chu et al [18] reported that when compared to those in Africa, the incidence rate of prostate cancer among African Americans was as high as 40 times, while Hsing et al in 2000 [72] showed that compared to men living in China, the prostate cancer incidence was 16-fold higher for Chinese men living in the USA, suggesting that environmental factors play an important role.

There are multiple evidences that certain foods are associated at higher risk, while others are even protective.

\section{Saturated animal fat}

Multiple ecological studies have shown a positive correlation between prostate mortality and per capita intake of meat, fat and dairy products $[73,74]$. A recent case-control study in patients less than or equal to 60 years found that high intake of total fat was associated with a statistically significant increase in prostate cancer risk [75].

There are several biological mechanisms that are thought to be involved between saturated animal fat intake and prostate cancer risk: 1) promoting prostate carcinogenesis via androgen; 2 ) increasing levels of reactive oxygen species (ROS) and increasing leukotrienes and prostaglandins levels from li- pid metabolism; and 3) increasing basal metabolism, insulin growth factor and tumor proliferation.

High-calorie intake of saturated animal fat has shown to increase the growth of prostate cancer cells by increasing the circulating levels of androgens [76, 77]. Furthermore, randomized cross-over studies involving low-fat and high-fat diets showed that the level of androgen is lower post-prandial as well as in vegetarians [78]. Finally, several studies reported that alteration of lipid levels undergoing to a low-fat diet reduces testosterone levels [79-81].

Excessive fat increases oxidative stress and ROS levels that attack the cells causing peroxidation and eventually DNA damage. A role for lipid metabolism and its metabolite have also been observed in mice and found that dietary fat is an important modulator of prostate cancer growth. For example, while some studies did not find any difference in terms of tumor growth and survival of mice placed on a Western diet, other studies showed a delay in cancer cell growth in mice with low-fat corn-oil diets, suggesting that the amount and type of fat are critical [82].

Mechanistically, corn-oil may promote cancer growth via the linoleic acid, the most abundant omega- 6 fat in the oil. Arachidonic acid which is a metabolite of linoleic acid gives rise to the formation of several pro-inflammatory prostaglandins (PG), including PGE2 that promotes cell proliferation, and 5 -hydroxyeicosatetraenoic acid that is produced by the action of 5-lipoxygenase, which is found to be increasingly expressed in malignant prostate cancer. Hence, a decrease in omega-6 fatty acid intake can decrease cancer growth. As opposite to omega- 6 fats pro-inflammatory effect, omega-3 fats are found beneficial against cancer growth [83].

\section{Red meat}

Dietary meat intake has been associated with prostate carcinogenesis by correlating cancer incidence and mortality with per capita meat consumption [84]. Rohrmann et al [85] showed that men consuming five or more servings of processed meat per week had a higher risk of prostate cancer when compared with men who consume one or fewer servings per week. In African-American men, there was no association observed with high consumption of red meats and increased prostate risk. However, there was a $20 \%$ increased risk for non-advanced prostate cancer in those consuming red meat cooked at high temperature [86]. Cooking at higher temperatures (125 - 300 ${ }^{\circ} \mathrm{C}$ ) causes the formation of aromatic hydrocarbons and mutagenic heterocyclic amines [87, 88]. Grilled or barbecued meat can result in the formation of $\mathrm{N}$-nitroso compounds that can result in lipid peroxidation and DNA damage by the production of free radicals $[89,90]$.

\section{Calcium, milk and dairy products}

Dairy foods have generally been associated with an elevated prostate cancer risk [85, 91-94]. Both calcium from supplements and dairy put male at high prostate cancer risk. Greater than 
2,000 mg per day of calcium was associated with a greater risk of prostate cancer. The Health Professional Follow-Up Study examined the diet of 47,885 men and looked closely at participants' consumption of animal food, protein and calcium [95]. After a 24-year follow-up, prostate cancer was diagnosed in 5,861 men, which was associated with high calcium intake [96].

\section{Vegetables}

Although conflicting results have been generated regarding dietary fat, a strong relationship was found between intake of Crucifers or Brassica vegetables (broccoli, Brussels sprouts, cauliflower, cabbage, and turnips) and reduced prostate cancer risk. Crucifers have anticancer properties mediated by phenyethyl isothiocyanate, sulforaphane, phytochemicals and indole-3-carbinol [97]. Some studies in the USA on a diet rich with broccoli have shown evidence for the protective effect of Brassica vegetables against prostate cancer [98]. However, some other studies revealed no anticancer capabilities of Brassica vegetables [99-102].

\section{Dietary soy and green tea}

Prostate cancer incidence is significantly lower in Asia when compared to North America, which has prompted research interest in the potential chemo-preventive action of soy and green tea which are a part of the diet in Asia. Decreased risk of prostate and several other cancers has been seen with consumption of soy and green tea [103-106]. Catechins found in green tea and isoflavones in soybeans have anticarcinogenic properties, and they inhibit different phases of carcinogenesis [107, 108] and metastasis [109-111]. Additionally, green tea polyphenols cause a reduction of IGF-1 levels [112-114].

\section{Tomatoes and lycopene}

Tomatoes seem to reduce the risk of prostate cancer. They contain high levels of lycopene which has potent anti-oxidant properties as well as cancer-preventive effects [115-119]. Lycopene also acts on the androgen receptors and reverses the effects of dihydrotestosterone and also inhibits insulin growth factor (IGF-I)-stimulation through Akt and GSK3 $\beta$ and tyrosine phosphorylation of GSK3 [120].

Tomato product consumption and lycopene intake were both associated with a decreased risk of prostate cancer [121]. The Health Professional Follow-Up Study showed a decreased risk of prostate cancer with 2 - 4 servings of tomato sauce per week [95]. Venkateswaran and Klotz [122] demonstrated that in the Lady transgenic mouse model, lycopene is able to reduce prostate cancer incidence only in association with selenium and vitamin $\mathrm{E}$.

On the other hand, an open phase II study of lycopene in advanced prostate cancer could not demonstrate any clinical benefit of this agent [123]. Similar results were seen in two other small epidemiological studies [124, 125]. Thus, the evi- dence of a connection between tomatoes assumption and prostate cancer risk requires further investigation.

\section{Vitamin and mineral supplements}

\section{Vitamin D}

An inverse relationship was observed between sunlight, or UVB exposure, and incidence of prostate cancer [126, 127], suggesting that vitamin D deficiency might increase prostate cancer risk development [128]. Similarly, discoveries were made by Barnett and Beer [129] who found that people living in "sunny" countries were at lower risk of developing secondary solid cancer after melanoma compared to people living in "less sunny" countries.

The incidence of prostate cancer in African-American men is twice that of Caucasians, suggesting that race might play a role. There might be a role for vitamin D deficiency in this as UV radiation is blocked in darkly pigmented skin due to high melanin levels and this mechanism inhibits the conversion to vitamin D3 [130].

Biochemical evidence supports a role for vitamin D in prostate growth $[131,132]$. Cell proliferation and invasion can be inhibited by vitamin $\mathrm{D}$ and its analogs, and stimulate cellular differentiation and apoptosis in prostate cancer cells as well as in tumor progression in animal models [132-134]. These findings provide a strong rationale for the use of vitamin $\mathrm{D}$ analogs as therapeutic agents for prostate cancer in a case that androgen deprivation therapy has failed [135]. Early clinical trials with $1 \alpha, 25(\mathrm{OH})_{2} \mathrm{D}_{3}$ revealed serious side effect such as hypercalcemia and hypercalciuria associated with its systemic administration $[136,137]$. Screening of several thousand vitamin D analogs identified a more potent and less calcemic compound compared to $1 \alpha, 25(\mathrm{OH})_{2} \mathrm{D}_{3}$ when was tested in nude mice to inhibit human prostate cancer cells growth [133, 134]. Further studies are needed to assess the use of vitamin D analogs as a chemopreventive or therapeutic approach in prostate cancer.

\section{Vitamin $E$}

Vitamin E is a vitamin which is fat soluble. Vegetable oils, egg yolks, and nuts are the important dietary sources of vitamin E. Tocopherols present in vitamin E have both potent cellular anti-oxidant with anticancer properties [54, 138]. Studies investigating the relationship between vitamin $\mathrm{E}$ and prostate cancer risk have shown contradicting results. The ATBC trial showed that in men who smoked supplementing daily vitamin E was not able to reduce the incidence of prostate cancer [139]. In another large clinical trial (SELECT trial), vitamin E supplementation did not show any benefit in 31,000 men with incident prostate cancer [140].

\section{Selenium}

Selenium is an essential micronutrient. It is found in the plants 
like tubers, cereals and legumes and animal products like meat, eggs, and seafood in the form of selenomethionine and selenocysteine. It has been inversely associated with several cancers, including prostate cancer.

Several studies have shown a 50-60\% risk reduction of developing prostate cancer when comparing high selenium consumption to low selenium consumption $[141,142]$. The NPC trial showed a $50 \%$ reduction of incidence of prostate cancer among men that were taking selenium supplementation [143]; however, SELECT trial did not report any beneficial effect of administering selenium alone or combination of selenium with vitamin E [140]. The different outcomes could result from the utilization of two different forms of selenium: selenized yeast in the NPC, whereas selenomethionine in the SELECT. These forms differ significantly in their biological effects, and it was shown they have different mechanisms of action. Selenomethionine acts on prostate cancer cells and induces cell cycle arrest [144, 145]. It can also act by inducing apoptosis and inhibiting angiogenesis $[145,146]$. Methylseleninic acid acts via a caspase-mediated pathway and induces apoptosis [147].

Interestingly, Chan et al [148] emphasized the role of genotype with respect to the effectiveness of selenium intervention. This study revealed that high selenium might be protective against an aggressive form of prostate carcinoma in men with the AA genotype of superoxide dismutase (SOD)-2 and increase the chances of having a worse tumor in men with a $\mathrm{V}$ allele. These data unveil the potential risks and benefits associated with selenium intervention in prostate cancer and may, in part, explain the conflicting results from other studies.

\section{Folate and vitamin B12}

Low folate and vitamin B12 can lead to altered methylation and lead to cancer development as these essential vitamins participate in DNA methylation, synthesis and repair [149]. In vitro [150], in vivo studies [151] and genetic studies [152, 153] on prostate cancer showed the role of folate in the development of an aggressive form of prostate cancer. Furthermore, elevated serum concentration of folate was associated with an increased proliferation of prostate cancer cells in some prostate samples collected from patients who underwent radical prostatectomy [154].

However, a recent meta-analysis reported that higher concentrations of vitamin $\mathrm{B}_{12}$ and folate have a modest $12 \%$ increased risk of prostate cancer [155]. In people who have prostate cancer, available data do not show an effect of consumption of folate on disease progression [156] or survival [157]. In conclusion, the association of folate and vitamin $B_{12}$ with prostate cancer is unclear and requires further investigation.

\section{Alcohol consumption}

The relationship between alcohol use and several types of human cancers, including prostate cancer, has been since long observed [158]. Heavy alcohol abuse ( $>15 \mathrm{~g}$ ethanol/day, or more than three drinks per day between wine, liquors or beer) may be a possible risk factor for prostate cancer and other cancers [159]. However, several cohort studies have suggested a weak correlation between alcohol intake and prostate cancer mortality [160-163], while others did not find any relation with increased risk [164]. As opposite, Dennis et al reported a significant relationship between higher alcohol intake and prostate cancer risk with a relative risk (RR) ranging from 1.05 to 1.21 for one or four alcoholic drinks per day, respectively $[165,166]$.

\section{Coffee}

Coffee consumption has been inversely associated with increased prostate cancer risk. Observational studies and some animal studies have revealed an association between long-term coffee drinking and improved glucose metabolism as well as insulin secretion [167]. Consistently, a reduced risk of type 2 diabetes was observed in those patients who reported higher consumption of coffee.

A large prospective study demonstrated that coffee intake was weakly inversely associated with overall risk of prostate cancer, while it significantly lowered the risk of lethal and advanced prostate cancer when heavy coffee drinkers are compared to the one that drinks less coffee [168]. Considering the effects of coffee consumption on insulin, antioxidants and androgens [169-174], the findings of this study are in agreement with the strongest associations between insulin, antioxidants and androgens with a lower incidence of prostate cancer in an advanced disease rather than for overall disease.

\section{Obesity, insulin and physical activity}

Obesity is linked to advanced and aggressive prostate cancer $[175,176]$, and high body mass index (BMI) is associated with more aggressive disease too and a worse outcome [121, 177].

The possible explanation is that most of the time obese men present with alteration of circulating levels of metabolic and sex steroid hormones, which are known to be involved in prostate development as well as oncogenesis [178].

Obesity, particularly when combined with physical inactivity, leads to the development of insulin resistance with reduced glucose uptake. That, in turn, leads to chronically elevated blood levels of insulin. Insulin is a hormone that promotes growth and proliferation, thus is reasonable to add it in the list of risk factors that promote prostate cancer initiation and/or progression [179]. Additionally, adipose cells represent a source of inflammation as well as of macrophages in adipose, which releases inflammatory mediators [180]. Three metaanalyses reported a modest but consistent association between obesity and prostate cancer incidence independently of BMI increase [181]. Data from three national surveys in the US population reported that obesity is associated with more aggressive prostate cancer and higher mortality despite its lower incidence [182].

One of the difficulties in interpreting results for obese men 
is that they have greater circulating plasma volume and therefore a "hemodilution" of PSA [183]. Consequently, they will less likely undergo a biopsy, and detect the presence of the tumor until a more advanced stage $[179,181]$. Because obesity is a potential factor leading to lower detection of prostate cancer, clinicians should consider BMI when interpreting PSA concentration. Physicians should be aware of these factors to avoid misdiagnosis among obese men and thus should include BMI along with other well-established risk factors (race, digital rectal examination (DRE) and family history) in the existing prostate cancer risk calculator [182].

Exercise is supposedly one of the easiest modifiable risk factor to manage in a way to obtain many benefits and relatively few side effects when it comes to prostate cancer prevention. Indeed, Keogh and McLeod found that veterans who exercised had a significantly lower risk of prostate cancer [184]. Prostate cancer patients who are committed to exercise display lower PSA levels and delay in initiating androgen deprivation therapy (ADT) by 2 years compared with less active peers and have a lower risk of high-grade disease, other than having a greater quality of life and less fatigue [184].

\section{Cigarette smoking}

Active and passive exposures to cigarette smoke are considered carcinogenic for many human cancers [185].

Association of smoking and prostate cancer risk may have either a hormonal or genetic basis. For instance, male smokers usually have higher levels of circulating sex hormones, which may increase prostate cancer risk or contribute to cancer progression [186, 187]. On the other hand, functional polymorphisms in genes involved in polycyclic aromatic hydrocarbons (PAHs) metabolism, one of the carcinogenic chemical of the cigarette smoke [185], may affect cancer onset and progression [188].

Most of the epidemiological studies have not found a relationship between smoking and incidence of prostate cancer, while some cohort studies have documented a 2 - 3 times higher risk in smokers of more than a pack a day compared with nonsmokers $[189,190]$. However, these studies have not demonstrated a convincing dose-response relationship, neither have they evaluated the influence of possible dietary risk factors that are confusing [189]. On the other hand, most studies examining the relationship between smoking and prostate cancer mortality demonstrated that smoking patients double the risk of dying from the disease compared to nonsmokers [189191]. Moreover, there is a dose-response relationship between the numbers of cigarettes per year of the smoker 10 years before diagnosis and the increased mortality risk [191].

\section{Sex hormones}

There is a large body of both historical and modern data supporting a role for androgens in prostate cancer pathogenesis and progression, also known as the "androgen hypothesis". In 1941, Huggins and Hodges proposed that prostate cancer growth was driven by androgens, after observing the benefits of castration in prostate cancer patients [192]. Several in vitro data obtained with well-differentiated prostate cancer cell lines showed that they respond to androgen stimulation and undergo apoptosis upon androgen withdrawal [193, 194]. Likewise, in vivo studies showed that androgens promote tumorigenesis and xenograft growth in animal models, and tumor regression is seen upon androgen deprivation $[195,196]$. Clinically, ADT remains a mainstay in prostate cancer treatment, especially in advanced disease [197]. Even though preclinical studies supported a role for androgens in prostate cancer pathogenesis, clinical data are still controversial [198].

Several evidences that the androgen pathway is one of the most important signaling mechanisms involved in prostate cancer come from gene linkage analysis, which reveals a significant association between prostate cancer risk and single nucleotide polymorphisms (SNPs) in the genes encoding enzymes involved in the synthesis of testosterone and dihydrotestosterone (DHT): hydroxysteroid (17-beta) dehydrogenase-1, hydroxy-delta-5-steroid dehydrogenase [199-202], $5 \alpha$-reductase-1 [203] and -2 [204-206], and CYP17, CYP3A4, CYP19A1 [207]. There is also an association between prostate cancer and the variants of androgen-responsive genes - kallikrein family, hK2 and PSA [208-210], and microseminoprotein [211-213], as well as genes involved in estrogen receptor signaling - estrogen receptors $\alpha$ [214] and $\beta[215,216]$. Further studies are needed to understand how those gene variations influence prostate cancer incidence.

Although the positive role of androgens on prostate cell growth has been established, some studies found that in prostate cancer patients, the testosterone and DHT levels were low, suggesting that non-androgenic hormones, including estrogens, insulin and vitamin D may be involved in the prostate carcinogenesis. Several studies have demonstrated that estrogen, including the natural hormone E2, induces multiple forms of genetic lesions such as chromosomal alterations, DNA damage, gene mutations, and microsatellite instability, strongly indicating that estrogen may serve as a carcinogen in the development of prostate cancer [217, 218].

\section{Insulin and insulin-like growth factor}

Hyperglycemia has been positively associated with cancers such as breast, pancreatic and colorectal [219]. However, its link with prostate carcinogenesis is conflicting. Several studies found evidence of higher risk of more aggressive or advanced prostate cancer among men with abnormal glucose levels, with the association being not significant in two of the studies [220223].

Conversely, several other studies reported a protective effect of hyperglycemia or type II diabetes against high-grade or more advanced prostate cancer [224-226]. For several decades, glucose has been documented as an important source of energy for rapid tumor cell proliferation [227]. Evidence from clinical and genetic studies has also linked the hyperglycemic environment to carcinogenic processes such as apoptosis, oxidative stress, DNA damage and chronic inflammation, which may drive the aggressiveness and progression of cancer [228-231]. 
Serum glucose is directly controlled by insulin, thus higher glucose level induces insulin secretion from pancreatic $\beta$ cells. Lehrer et al showed that patients with high-risk prostate cancer had higher insulin levels [171]. In addition, diet-induced hyperinsulinemia was associated with increased tumor growth in a xenograft model [232]. Finally, the high level of circulating insulin decreases the production of insulin-like growth factor (IGF-1)-binding proteins, increases the level of IGF-1 and increases the production of advanced glycation end products, which promote carcinogenesis [233].

In the past years, several studies have recognized a crucial role for the components of IGF system in prostate cancer biology and its implication in both mitogenic and anti-apoptotic events in prostate cancer cell lines [234]. The IGF family is composed of two receptors (insulin receptor (INSR), IGF-1 receptor (IGF-1R) and mannose 6-phosphate receptor (M6P/ IGF-2R)), three ligands (insulin, IGF-1 and IGF-2) and six known types of circulating IGF-binding proteins (IGFBP1-6) that modulate the bioavailability and bioactivity of the IGFs [235]. The IGF system regulates many important cellular processes critical for normal prostate growth and development, such as proliferation, differentiation and cellular metabolism. The relevance of the IGF system has been evaluated in several studies. Increased serum concentration of IGF-1 was correlated to higher risk of prostate cancer [236-238].

However, preclinical studies [239-241] as well as clinical studies [291, 292] showed conflicting results. Therefore, whether IGF-1 serum levels can be used as a prognostic tool requires further investigation.

\section{Chronic inflammation and prostatitis}

There is a strong link between prostate cancer and inflammation, and in 1863, Rudolf Virchow was the first to identify the high density of leukocytes in neoplastic samples, suggesting a positive association between inflammation and cancer [242]. After that, both epidemiological and biological studies provided evidence that inflammation is behind the high-grade or aggressive prostate tumors and ultimately metastatic spread $[174,243]$. The evidence-based knowledge so far supports the role of inflammatory responses in the regulation of tumor microenvironment through the remodeling of the extracellular matrix (ECM) and initiation of epithelial-mesenchymal transition (EMT). Indeed, inflammatory cells release growth factors and cytokines within the tumor microenvironment to promote angiogenesis and remodeling of the ECM, while further inflammatory cytokines released within the reactive stroma induce EMT-mediated responses [244].

Patients with elevated PSA often present with intraprostatic inflammation detected with biopsies [245]. Recently, an inflammatory effector, pentraxin 3 , has been identified as a biomarker for predicting tumor progression due to prostatic inflammation in prostate cancer patients [246].

Chronic inflammation causes proliferative inflammatory atrophy (PIA) [174], which may develop prostatic intraepithelial neoplasia (PIN) a well-known precursor of prostate cancer [247]. Consistently with the tight connection between chronic inflammation and high-grade prostate cancer [243], several
SNPs in genes involved in inflammation, such as cyclooxygenase (COX-2) [248, 249], interleukin-1 (IL-1) [250], IL-6 [251, 252], IL-8 [250] and IL-10 [250, 253], tumor necrosis factor- $\alpha(\mathrm{TNF}-\alpha)$ [254] and Toll-like receptor-4 (TLR4) [253, 255-257] were associated to prostate cancer risk.

Prostatitis is the inflammation of the prostate gland that is hard to diagnose because it is often asymptomatic [258]. Notably, men with symptoms of prostatitis are more likely to be diagnosed with prostate cancer as a result of the increased prevalence of biopsy [259].

Lu et al conducted a study including cases and controls from Minnesota and found that there was a significant association between prostatitis and prostate cancer (odds ratio $=1.7$; 95\% confidence interval: 1.1 - 2.6) [260]. A first meta-analysis involving 11 studies between 1971 and 1996 provided statistical evidence that prostatitis is a significant risk factor in prostate cancer [261]. This observation was confirmed later with another meta-analysis that included studies between 1990 and 2012 [262].

Development of prostatitis is induced by one or a combination of factors including infections, chemical and physical trauma, and diet. Chemical irritation because of urine reflux, or abnormal flow of urine from the bladder back through the ureters, may cause chronic inflammation in the prostate [263]. Non-sexually transmitted pathogens such as E. coli and Propionibacterium acnes can cause acute and chronic prostatitis $[264,265]$. Also, many sexually transmitted organisms, including Neisseria gonorrhea [266] and Chlamydia trachomatis [267], can induce chronic infection and inflammation, that potentially increase the risk of developing prostate cancer [268].

It appears clear that inflammation is the ubiquitous factor associated with increased risk of prostate cancer, independently of its source (either pathogens or environmental factors).

Finally, the several signaling pathways involved in the inflammatory process that modifies prostate microenvironment and the complexity of biological events linking inflammation to prostate cancer progression and metastatic spread provide a broad range of promising targets for pharmaceutical treatments.

\section{Sexually transmitted disease (STD)}

Several epidemiologic studies evidenced that factors related to sexual behavior and STDs may be associated with prostate cancer [269].

STDs represent a major public health problem worldwide. Human papilloma virus (HPV) and herpes simplex virus (HSV) are common STDs worldwide [270, 271], the former being also involved in the etiology of cancer of cervix uteri and other anatomical sites [272, 273]. The first claims of an etiological role of STDs in the development of prostate cancer date back to the 1950s [274] and several mechanisms were subsequently proposed to explain this association. For gonorrhea and other bacterial infections, prostate inflammation and prostate atrophy are the processes that lead to prostate cancer, whereas for viral infections, the emphasis was placed on the transforming properties of viruses, in particular, HSV [275].

A large population-based case-control study among Af- 
rican-American and white men, revealed an elevated risk of prostate cancer among men with a history of gonorrhea or syphilis [268]. HPV, which occurs in human prostate cancer and benign prostatic tissue [276], has been shown to transform human prostate cells in vitro. Furthermore, seropositivity for HPV-18 and HPV-16 has been associated with subsequent prostate cancer in a Finnish cohort study [277, 278], but a small case-control study of HPV-16 and HPV-11 [279], and a large population-based case-control study [268] showed little evidence of risk. Finally, a recently published meta-analysis showed a weak association between HPV-16 and prostate cancer and no association for HPV-18 [280].

To our knowledge, only three studies have been published so far investigating the association between Trichomonas vaginalis infection, a common cause of vaginitis in women, and prostate cancer risk. Trichomonas vaginalis can also infect men, where it may cause asymptomatic urethritis and prostatitis. In particular, its frequent asymptomatic presentation may make it possible to persist untreated and ascend to the prostate, where it can establish foci of chronic inflammation that may eventually lead to prostate cancer [275]. Mechanistically, Trichomonas vaginalis infection causes adherence of the protozoan to epithelial cells by decreasing the expression of anti-apoptotic genes; it also alters the production of IL-6 and monocyte chemotaxis proteins. Whereas an association between Trichomonas vaginalis serostatus and increased risk of prostate cancer was found, the same connection between seropositivity for this pathogen and progression to death from prostate cancer was not demonstrated [281].

\section{Medications}

Despite the knowledge gained over the years about the etiopathogenesis of prostate cancer and the known high risk for men to be diagnosed with the disease during their lifetime, effective chemo-preventive agent that can safely be administered to impact the lives of men is still missing positively. The role of testosterone and pro-inflammatory pathways in the pathogenesis of prostate cancer provided some clues about the possibility to use inhibitors of testosterone endogenous production and inflammation.

\section{5- $\alpha$ reductase (5-AR) inhibitors}

By far the most promising and well-studied chemo-preventive agents are finasteride and dutasteride, which are inhibitors of 5-AR enzyme that converts testosterone into dihydrotestosterone, the most prevalent and potent androgen in prostate tissue, which is responsible for embryologic development [282] and growth of the prostate as well as promotion of prostate cancer [283].

Finasteride and dutasteride are effectively used for the treatment of benign prostatic hyperplasia [284-286] and were studied in clinical trials as potential chemopreventive agents.

Finasteride was studied in the prostate cancer prevention trial (PCPT) and its use was associated with a $25 \%$ reduction in prostate cancer incidence after 7 years [287]. Dutasteride was studied in the REduction by DUtasteride of Prostate Cancer Events (REDUCE) trial, and the results showed that men treated with dutasteride had a $23 \%$ reduction in prostate cancer incidence after 4 years [288]. However, the results of these two trials were largely criticized for many aspects, including results from biopsies performed towards the end of the study as opposed to biopsies that are done when patients have elevated PSA or DRE abnormalities, the capability to prevent only low-grade cancers that will unlikely lead to death. Most importantly, Food and Drug Administration (FDA) Oncology Drugs Advisory Committee (ODAC) re-analyzed the data from PCPT and REDUCE trials and confirmed that the results do not strongly support any preventive effect on high-grade prostate cancer and therefore their use in therapy as chemopreventive agents is not recognized yet.

The Reduction by Dutasteride of Clinical Progression Events in Expectant Management of Prostate Cancer (REDEEM) study reported that dutasteride may provide a useful adjunct to "active surveillance" for management of prostate cancer, because it delayed the time to prostate cancer progression, increased the percent of men with no detectable tumor and improved cancer-related anxiety [289].

However, whether the effectiveness of 5-AR inhibitor therapy is influenced by certain patients' features, like specific clinical conditions or genetic variations, was not evaluated yet. Therefore, identification of these subgroup of patients who may then undergo clinical trials with 5-AR inhibitors would address this intriguing question.

Nonsteroidal anti-inflammatory drugs (NSAIDs) and aspirin (ASA)

There is rapidly growing evidence for the impact of NSAIDs on cancer [290]. At the cellular level, NSAIDs target cyclooxygenase (COX), particularly, the isoform 2 (COX-2) is expressed in inflammatory cells of the prostate and in PIA, a precursor of prostate cancer [174, 243]. A recent meta-analysis that included 20 observation studies with a total of 25,768 individuals evaluated the efficacy of NSAIDs in reducing prostate cancer risk [291]. The clinical data indicated that there was a statistically significant protective effect as revealed by the risk reduction at $5 \%$ for ASA and $8 \%$ for other NSAIDs. In addition, another study revealed that they were only effective for patients $>60$ years of age [292].

Several experimental studies have documented that COX2 overexpression in prostate cancer can be effectively targeted by COX-2 selective inhibitors such as celecoxib [291].

Several epidemiological and experimental evidence has demonstrated an inverse relationship between ASA use and prostate cancer, particularly after 5 or more years of use in men with metastatic disease [293]. A population-based casecontrol study of 1,900 men reported that the RR of prostate cancer was significantly reduced of $18 \%, 21 \%$ and $24 \%$ in men who reported the use of ASA, or currently used ASA, or are long-term users of ASA, respectively [294]. Surprisingly, low dose of ASA was associated with the highest risk [294]. Fi- 
nally, a multicenter study of over 90,000 documented a direct protective effect in patients ingesting six ASAs daily [295]. Altogether, the results of these studies have shown that the use of NSAID and ASA have a beneficial effect on the prevention of prostate cancer.

\section{Statin}

Statin medications are inhibitors of the synthesis of lipids, particularly cholesterol and recently they showed to reduce PSA levels [296, 297], and the risk of advanced or aggressive prostate cancer [298]. They are also associated with improved outcomes after radiation therapy [299] and radical prostatectomy [300], although data for the latter are conflicting [301].

The use of statins as a preventive agent may offer the advantage to reduce cholesterol levels and the risk of cardiac disease other than being safe. Statins effect as a secondary preventive agent was recently tested in two studies. One trial enrolled patients and randomly assigned them to simvastatin or placebo treatment before radical prostatectomy and examined changes in benign and malignant tissue in the prostate specimen [302]. From this study, no significative beneficial action of simvastatin was observed and its use was associated to serious adverse events ( $+55 \%$ vs. $18.75 \%$ of placebo group). The second trial is a phase II study evaluating the effect of atorvastatin and celecoxib on the levels of prostate cancer biomarkers, including PSA, in those patients with rising PSA levels after definitive local therapy [303].

In conclusion, more clinical evidence is called to prove the effective advantage of using statins for prostate cancer prevention.

\section{Environmental carcinogens}

The slow process of prostate carcinogenesis is also influenced by exposure to certain environmental factors that increase the risk of developing cancer. These include insecticides, herbicides and other organic compounds.

\section{Agent orange (AO)}

Herbicides are active chemical compounds that are used to fight plant pests. Agent orange (AO) is a mixture of two herbicides that were used as a defoliant between 1962 and 1971 in the Vietnam War and was contaminated with the toxin 2,3,7,8-tetrachlorodibenzo-p-dioxin (TCDD), a putative carcinogen. Dioxins remain an area of important interest as these environmental toxins continue to be produced through chemical processing and municipal waste incineration. These chemicals can then enter the food chain through soil contamination [304].

In 1998, the National Academy of Science of the US recognized a positive association between herbicide exposure and many human cancers. In a review published in 2008, the authors found twice as many cases of prostate cancer among the exposed veterans of the Vietnam War compared with noexposed veterans [305]. They presented with earlier diagnostic ages, high-grade tumor, independently of other modifiable risk factors. It suggests that $\mathrm{AO}$ is the most predictive factor not only of developing prostate cancer but also of a higher histological grade and a greater probability of metastatic disease at diagnosis. These data were later confirmed by the study of Ansbaugh et al that demonstrated a high correlation between $\mathrm{AO}$ exposure and risk of high-grade prostate cancer among Vietnam War veterans [304].

\section{Chlordecone}

Chlordecone (also known as Kepone) is an organochlorine insecticide with well-defined estrogenic properties [306, 307] extensively used for decades in the French West Indies, to control the banana root borer. It is a carcinogenic agent with a long biologic half-life, and among its long-term effects, cancer is not excluded. Indeed, it was shown that chlordecone causes hepatic tumors in laboratory mice and rats [308] and it has been associated with increased risk of prostate cancer too.

The prostate cancer risk associated with chlordecone exposure was higher in those men with a family history of prostate cancer, and similar findings were reported for pesticide exposure in the Agricultural Health Study [309-312]. There are two possible explanation: 1) Study subjects and their first-degree relatives may have similar patterns of exposure, which consequently lead to a statistical interaction between chlordecone exposure and family history of prostate cancer; 2) Genetic variations, such as inheritance of polymorphism in a metabolic enzyme that alters the balance between chlordecone bioactivation and detoxification in the body. In line with the latter hypothesis, previous studies have shown differences in the inter-individual liver activity of chlordecone reductase between White and Japanese men [313, 314].

\section{Bisphenol A (BPA)}

Another harmful compound associated with a high risk of prostate cancer is BPA.

BPA has been used to harden plastic since the 1950s in the manufacture of polycarbonate plastic and epoxy resins that appear in thousands of consumer products since then [315]. BPA is also used as a cross-linking compound in many food product containers [316]. BPA leaching from these containers may contaminate food and beverage, which constitutes the main source of exposure of humans via a route of ingestion [317].

Approximately $90 \%$ of BPA exposure in humans is from the intake of BPA contaminated food and beverage during processing and storage [318]. In addition to ingestion, intake of BPA from the routes of inhalation or absorption via direct contact cannot be ignored [317, 319].

The first evidence on the direct link between BPA exposure and human prostate cancer was reported in 2014 by two US research teams based on in vitro and in vivo experimental studies [320,321]. Abnormalities of centrosome (a hallmark of 
malignant transformation) induced by a low level of BPA and its analogs were underlined as the potential mechanism in promoting the formation of prostate cancer [320, 322]. Tse et al published epidemiological evidence that cumulative exposure to BPA was associated with an excess risk of prostate cancer in the Chinese population [323]. The authors found a positive association of prostate cancer with intake of deep-fried food and pickled vegetable that were independent of other risk factors [324-326]. Deep fried foods (e.g. meats and potato) at highheat cooking process generate a high amount of heterocyclic amines and other mutagens and carcinogens (e.g. acrylamide and polycyclic aromatic hydrocarbons) that may be carcinogenic to prostate cells [325].

\section{Vasectomy}

Vasectomy is the most frequent male contraception in the USA, with approximately 500,000 procedures performed annually. Its association with prostate cancer risk was explored in case-control and cohort studies with conflicting results. Some authors found an increased risk of up to $70 \%$ with a vasectomy, while others found a lesser risk [189, 327, 328]. However, studies showing small RRs are not convincing as they have some potential bias and methodological shortcoming [329]. On the other hand, in a very well-designed study in New Zealand, the country with the highest global prevalence of vasectomy, the authors found no relationship with these subgroups [327].

Biological studies that show underlying mechanism/s that might explain an association between vasectomy and prostate cancer are still lacking.

\section{Ejaculatory frequency}

Over the years, there has been growing evidence of a link between ejaculation and lower chances of prostate cancer.

In 2004, the Health Professionals Follow-Up Study (HPFS) cohort reported a significant positive relation between monthly ejaculation frequency and prostate cancer risk based on 8 years of follow-up [330].

A major study of 2016 that involved almost 32,000 men revealed that men who ejaculated $\geq 21$ times per month (EPM) had about a $20 \%$ lower chance of low-grade prostate cancer, compared with those who had $\leq 4-7$ EPM based on 18 years follow-up [331]. A year later, a case-control study sampling a smaller group of men $(2,141)$ from age 20 to 50 found only weak evidence of an inverse association between ejaculatory frequency in the fourth decade of life and advanced prostate cancer, which was not significantly modified by a number of new sexual partners [332]. In the same study, no relationship was found for ejaculatory frequency in the third and fifth decades of life.

The ejaculatory frequency may influence prostate cancer development through several mechanisms. One biological mechanism is described as "prostate stagnation hypothesis", which involves the prostatic accumulation of potentially carcinogenic secretions that may create a favorable environment for prostate cancer development [330, 333]. More frequent ejaculation may alter the function of peripheral-zone epithelial cells, which start to oxidate citrate rather than secrete it. This metabolic switch is known to occur early in prostate tumorigenesis [334]. Finally, the higher ejaculatory frequency may reduce the development of prostatic intraluminal crystalloids, which have been associated with a higher risk of prostate cancer $[335,336]$. More frequent ejaculation is thought to help to lower psychological tension and favors central sympathetic nervous system suppression, which could dampen the stimulation of prostate epithelial cell division [337].

\section{Diagnostic radiologic procedure and ultraviolet light expo- sure}

The radiation generated from X-ray, CT and nuclear imaging is ionizing radiation that penetrates the tissue to reveal the body's internal organs. However, ionizing radiation can damage DNA, and although cells repair most of the damage, sometimes small area may remain altered ("misrepair" area) consequently leading to DNA mutations that may contribute to cancer development years down the road. The first study investigating the connection between low-dose ionization radiation from diagnostic X-ray procedures and risk for prostate cancer reported that exposure to a hip/pelvic X-ray significantly increased prostate cancer risk independently of other known risk factors such as family history of cancer [338]. However, unless men were exposed to high doses of radiation during cancer treatment in youth, any increase in the risk for cancer due to medical radiation appears to be slight. Considering that the increase in high-dose imaging has occurred only since 1980 and the effects of radiation damage typically take many years to appear, this may explain the weak association between ionizing radiation and prostate cancer risk observed thus far.

Finally, exposure to solar UV radiation is inversely associated with both the incidence and mortality of prostate cancer [128]. The biological explanation of this fact is based on the synthesis and physiological actions of vitamin D [126, 127, 129].

\section{Prevention}

An effective prevention strategy for prostate cancer would provide many benefits to men with a substantial positive impact on public health, including the potential to reduce the high lifetime risks of prostate cancer development, the morbidities associated with cancer treatment, especially in those newly diagnosed patients with biological indolent prostate cancer that still undergo curative-intent therapy rather than active surveillance and finally the inability to eradicate life-threatening metastatic prostate cancer.

Epidemiological data indicate a dominant role for lifestyle factors in prostate cancer development. Considering that prostatic carcinogenesis takes many decades, lifestyle modification may represent a feasible and cost-effective approach to retard prostate cancer development.

Although the data about the role of specific lifestyle fac- 
tors fostering prostate cancer development have often been conflicting, most of the studies clearly evidence a diet rich in fruits, vegetables and anti-oxidant micronutrients, and poor in saturated fats and "well-done" red meats, may significantly reduce risks of prostate cancer development, as well as the risk of diseases typical of the industrialized world.

The better understanding of prostate cancer etiology represents the key to open to new opportunities for prostate cancer prevention. Several nutrients and pharmaceutical agents have been studied as potential chemoprevention candidates. Vitamin E and selenium showed promise [138, 141]. However, these were definitively evaluated in the SELECT, and neither agent reduced prostate cancer risk [140]. Vitamin D analogs, NSAIDs and toremifene (a selective estrogen receptor modulator) have all been evaluated in laboratory and/or observational studies [134, 339, 340]. However, vitamin D has not been formally tested in primary prevention trials, while the NSAID rofecoxib, a COX-2 selective inhibitor, could not be successfully tested because the trial was closed when the drug was withdrawn from the market after an interim safety analysis indicated that the drug was associated with increased risk of cardiovascular events within the Adenomatous Polyp Prevention on Vioxx (APPROVe) trial [341]. Toremifene showed a modest risk reduction in a phase II trial [342], but no significant risk reduction in a phase III trial [343].

Besides identification of molecular targets, other principles of prevention include personalized risk assessment, identification of sensitive and accurate surrogate molecular markers to serve as intermediate endpoints and identification of biomarkers that predict sensitivity to preventive agents. Furthermore, it should also emphasize personalized molecularly targeted approaches for the selection and treatment of patients with prostate cancer that result in a positive outcome and effective therapy.

\section{Future Directions}

The high global incidence of prostate cancer makes a call to strengthen the current tools available to identify trends and prevention strategies to reduce the public health impact of this disease in the future.

First, prostate cancer registries play an important role in the advancement of prostate cancer research and care. Indeed, they represent an essential source to collect information about incidence and mortality, disease characteristics at presentation, trends and risk factors, quality of care, disparities in access to treatment, long-term data related to oncologic and healthrelated quality of life outcomes and costs associated with management of the disease. Therefore, improvements in the quality of data, collection of tissue samples and the availability of data feedback to health care providers will increase the relevance of epidemiological studies especially when it comes to the evaluation of data collected from undeveloped countries.

Chemo-preventive strategies have been explored in several preclinical and small clinical studies to mitigate the global burden of prostate cancer and the overtreatment of indolent disease that has been associated with the broad utilization of
PSA testing. However, a challenge for the future will be the translation of preclinical data into clinically useful strategies, which will require very large trials with thousands of participants, like those of the SELECT studies [180].

Furthermore, studies that can fill the knowledge gap regarding the higher prostate cancer incidence and mortality in African-American men compared to White men are also needed. Recently, the "Research on Prostate Cancer in Men of African Ancestry: Defining the Roles of Genetics, Tumor Markers, and Social Stress" (RESPOND) study which was funded by the National Institute of Health and Prostate Cancer Foundation was carried out. The primary goals of this study were to understand how social and genetic variants contribute to the development of aggressive prostate cancer, and how those factors interact with each other. Hopefully, the increased knowledge gained within this study will provide new insights to develop positive screening and chemo-preventive strategies.

Finally, classical prognostic factors such as PSA testing, Gleason score and clinical cancer staging have demonstrated not to be always sufficient to lead to a clinically relevant cancer diagnosis. Considering that various genomic aberrations contribute to the variety in prostate cancer risk and outcome as well as drug responses and progression between patients, the identification of novel genetic biomarkers is highly required. This will undoubtedly improve cancer diagnosis, subtype identification and risk stratification. Most importantly, as we are moving toward personalized medicine, oncogenetic testing and biomarker profiling will facilitate the optimal therapeutic intervention based on the alterations observed in single patients $[344,345]$. Clinical trials have already shown high success rate for drugs that are developed using biomarkers in patients with non-small cell lung cancer, therefore it is desirable that same results may also be achieved for the treatment of prostate cancer.

\section{Conclusion}

Prostate cancer is the most common malignancy in men, ranking second after lung cancer [1]. The identification of biomarkers such as PSA that are positively correlated with the diagnosis of prostate cancer revolutionized the epidemiology of this disease. Indeed, since the introduction of PSA testing and subsequent biopsies, USA registered double of prostate cancer incidence starting from the late 1980s [23]. A similar increase was also reported in other countries, particularly in the western type. Unfortunately, although it turned effective in reducing prostate cancer-specific mortality, the relevant overdiagnosis and the severe side effects of treatments advised against the introduction of PSA as a screening program.

Perhaps, the most dramatic statistic when it comes to prostate cancer incidence and mortality is the way that prevalence varies among different racial groups, with the highest prevalence in African-American men [14]. Both biologic and socioeconomic factors may explain this discrepancy, but which genes may be involved and how they may interact with the environment is still unknown and is a subject of studies. In 2018, a study called "Research on Prostate Cancer in Men of Afri- 
can Ancestry: Defining the Roles of Genetics, Tumor Markers, and Social Stress" (RESPOND) was financed by the National Cancer Institute, the National Institute on Minority Health and Health Disparities and the Prostate Cancer Foundation with the purpose of addressing those questions.

In recent years, the development of novel genetic technologies allowed for the first time a comprehensive analysis of genetic and epigenetic changes in human prostate cancer. This information, combined with targeted functional studies, helped to identify critical signaling pathways that are casually involved in prostate cancer initiation and progression. This information will provide an opportunity for the development of novel targeted approaches for therapeutic interventions. More research to identify genes associated with an increased risk of prostate cancer is ongoing, and researchers are collecting more insights about the impact that specific genetic changes have on prostate cancer development.

Although there are no studies that can sufficiently demonstrate the direct correlation between diet and nutrition with risk or prevention of prostate cancer development, many preclinical studies that look at links between certain eating behaviors and cancer suggest there may be a connection. Moreover, these studies allowed identifying the underlying biological mechanisms that may explain this link. Therefore, well-designed trials that replicate preclinical findings are warranted to validate the impact of dietary agents in prostate cancer. Finally, future chemoprevention studies should include not only early intervention but should also emphasize personalized molecularly targeted approaches for the selection and treatment of patients with prostate cancer that result in a positive outcome and effective therapy.

\section{Acknowledgments}

None.

\section{Conflict of Interest}

None of the authors have conflict of interest.

\section{Ethics Approval}

No ethics approval needed.

\section{Funding}

No funding to disclose.

\section{Author Contributions}

Conception and design: PR. Analysis and interpretation, drafting and critical revision of the article: PR. Final approval of the article: PR.

\section{References}

1. Bray F, Ferlay J, Soerjomataram I, Siegel RL, Torre LA, Jemal A. Global cancer statistics 2018: GLOBOCAN estimates of incidence and mortality worldwide for 36 cancers in 185 countries. CA Cancer J Clin. 2018;68(6):394424.

2. Ferlay J EM, Lam F, Colombet M, Mery L, Pineros M, Znaor A, Soerjomataram I, et al. Global cancer observatory: cancer today. Lyon, France: International Agency for Research on Cancer. Available from: https:/gco.iarc. fr/today, Accessed 02 February 2019. [Internet].

3. Panigrahi GK, Praharaj PP, Kittaka H, Mridha AR, Black OM, Singh R, Mercer R, et al. Exosome proteomic analyses identify inflammatory phenotype and novel biomarkers in African American prostate cancer patients. Cancer Med. 2019.

4. Ferlay J EM, Lam F, Colombet M, Mery L, Pineros M, Znaor A, Soerjomataram I, et al. Global cancer observatory: cancer tomorrow. Lyon, France: International Agency for Research on Cancer. Available from: https://gco.iarc. fr/tomorrow, Accessed 02 February 2019. [Internet].

5. Chan JM, Gann PH, Giovannucci EL. Role of diet in prostate cancer development and progression. J Clin Oncol. 2005;23(32):8152-8160.

6. Giovannucci E, Rimm EB, Colditz GA, Stampfer MJ, Ascherio A, Chute CG, Willett WC. A prospective study of dietary fat and risk of prostate cancer. J Natl Cancer Inst. 1993;85(19):1571-1579.

7. Kolonel LN, Nomura AM, Cooney RV. Dietary fat and prostate cancer: current status. J Natl Cancer Inst. 1999;91(5):414-428.

8. Platz EA, Leitzmann MF, Michaud DS, Willett WC, Giovannucci E. Interrelation of energy intake, body size, and physical activity with prostate cancer in a large prospective cohort study. Cancer Res. 2003;63(23):8542-8548.

9. Willis MS, Wians FH. The role of nutrition in preventing prostate cancer: a review of the proposed mechanism of action of various dietary substances. Clin Chim Acta. 2003;330(1-2):57-83.

10. Perdana NR, Mochtar CA, Umbas R, Hamid AR. The Risk Factors of Prostate Cancer and Its Prevention: A Literature Review. Acta Med Indones. 2016;48(3):228-238.

11. SEER Cancer Statistics Review, 1975-2013 [Internet]. National Cancer Institue, Bethesda, MD. 2016. Available from: https://seer.cancer.gov/csr/1975_2015/. Accessed 04 February 2019. [Internet]. SEER, 2018. Available from: https://seer.cancer.gov/explorer/application.php.

12. Quinn M, Babb P. Patterns and trends in prostate cancer incidence, survival, prevalence and mortality. Part I: international comparisons. BJU Int. 2002;90(2):162-173.

13. Epidemiology of prostate cancer in Europe [Internet]. European Commission, 2015. Available from: https:// ec.europa.eu/jrc/en/publication/epidemiology-prostatecancer-europe.

14. Cancer Stat Facts: Prostate Cancer [Internet]. SEER, 2018. Available from: https://seer.cancer.gov/statfacts/ $\mathrm{html} /$ prost.html. 
15. Draisma G, Etzioni R, Tsodikov A, Mariotto A, Wever E, Gulati R, Feuer E, et al. Lead time and overdiagnosis in prostate-specific antigen screening: importance of methods and context. J Natl Cancer Inst. 2009;101(6):374383.

16. Etzioni R, Penson DF, Legler JM, di Tommaso D, Boer R, Gann PH, Feuer EJ. Overdiagnosis due to prostate-specific antigen screening: lessons from U.S. prostate cancer incidence trends. J Natl Cancer Inst. 2002;94(13):981990.

17. Kheirandish $\mathrm{P}$, Chinegwundoh F. Ethnic differences in prostate cancer. Br J Cancer. 2011;105(4):481-485.

18. Chu LW, Ritchey J, Devesa SS, Quraishi SM, Zhang $\mathrm{H}$, Hsing AW. Prostate cancer incidence rates in Africa. Prostate Cancer. 2011;2011:947870.

19. Force USPST, Grossman DC, Curry SJ, Owens DK, Bibbins-Domingo K, Caughey AB, Davidson KW, et al. Screening for prostate cancer: US preventive services task force recommendation statement. JAMA. 2018;319(18):1901-1913.

20. Negoita S, Feuer EJ, Mariotto A, Cronin KA, Petkov VI, Hussey SK, Benard V, et al. Annual Report to the Nation on the Status of Cancer, part II: Recent changes in prostate cancer trends and disease characteristics. Cancer. 2018;124(13):2801-2814.

21. Oliver JS. Attitudes and beliefs about prostate cancer and screening among rural African American men. J Cult Divers. 2007; 14(2):74-80.

22. Taitt HE. Global Trends and Prostate Cancer: A review of incidence, detection, and mortality as influenced by race, ethnicity, and geographic location. Am J Mens Health. 2018;12(6):1807-1823.

23. Jemal A, Fedewa SA, Ma J, Siegel R, Lin CC, Brawley O, Ward EM. Prostate cancer incidence and PSA testing patterns in relation to USPSTF screening recommendations. JAMA. 2015;314(19):2054-2061.

24. Mottet N, Bellmunt J, Bolla M, Briers E, Cumberbatch MG, De Santis M, Fossati N, et al. EAU-ESTRO-SIOG Guidelines on Prostate Cancer. Part 1: Screening, Diagnosis, and Local Treatment with Curative Intent. Eur Urol. 2017;71(4):618-629.

25. Baade PD, Youlden DR, Krnjacki LJ. International epidemiology of prostate cancer: geographical distribution and secular trends. Mol Nutr Food Res. 2009;53(2):171-184.

26. Collin SM, Martin RM, Metcalfe C, Gunnell D, Albertsen PC, Neal D, Hamdy F, et al. Prostate-cancer mortality in the USA and UK in 1975-2004: an ecological study. Lancet Oncol. 2008;9(5):445-452.

27. Etzioni R, Tsodikov A, Mariotto A, Szabo A, Falcon S, Wegelin J, DiTommaso D, et al. Quantifying the role of PSA screening in the US prostate cancer mortality decline. Cancer Causes Control. 2008;19(2):175-181.

28. Lim LS, Sherin K, Committee APP. Screening for prostate cancer in U.S. men ACPM position statement on preventive practice. Am J Prev Med. 2008;34(2):164-170.

29. Andriole GL, Crawford ED, Grubb RL, 3rd, Buys SS, Chia D, Church TR, Fouad MN, et al. Mortality results from a randomized prostate-cancer screening trial. N Engl J Med. 2009;360(13):1310-1319.
30. Schroder FH, Hugosson J, Roobol MJ, Tammela TL, Ciatto S, Nelen V, Kwiatkowski M, et al. Screening and prostate-cancer mortality in a randomized European study. N Engl J Med. 2009;360(13):1320-1328.

31. De Angelis R, Sant M, Coleman MP, Francisci S, Baili $\mathrm{P}$, Pierannunzio D, Trama A, et al. Cancer survival in Europe 1999-2007 by country and age: results of EUROCARE - 5-a population-based study. Lancet Oncol. 2014;15(1):23-34.

32. Prostate Cancer Survival Rates [Internet]. 2018. Available from: https://www.pcf.org/about-prostate-cancer/ what-is-prostate-cancer/prostate-cancer-survival-rates/.

33. Bostwick DG, Burke HB, Djakiew D, Euling S, Ho SM, Landolph J, Morrison H, et al. Human prostate cancer risk factors. Cancer. 2004;101(10 Suppl):2371-2490.

34. Dagnelie PC, Schuurman AG, Goldbohm RA, Van den Brandt PA. Diet, anthropometric measures and prostate cancer risk: a review of prospective cohort and intervention studies. BJU Int. 2004;93(8):1139-1150.

35. Pienta KJ, Esper PS. Risk factors for prostate cancer. Ann Intern Med. 1993;118(10):793-803.

36. Kolonel LN, Altshuler D, Henderson BE. The multiethnic cohort study: exploring genes, lifestyle and cancer risk. Nat Rev Cancer. 2004;4(7):519-527.

37. Kolonel LN. Fat, meat, and prostate cancer. Epidemiol Rev. 2001;23(1):72-81.

38. Wolk A. Diet, lifestyle and risk of prostate cancer. Acta Oncol. 2005;44(3):277-281.

39. Wilson KM, Giovannucci EL, Mucci LA. Lifestyle and dietary factors in the prevention of lethal prostate cancer. Asian J Androl. 2012;14(3):365-374.

40. Markozannes G, Tzoulaki I, Karli D, Evangelou E, Ntzani E, Gunter MJ, Norat T, et al. Diet, body size, physical activity and risk of prostate cancer: An umbrella review of the evidence. Eur J Cancer. 2016;69:61-69.

41. Scardino PT. Early detection of prostate cancer. Urol Clin North Am. 1989;16(4):635-655.

42. Wu I, Modlin CS. Disparities in prostate cancer in African American men: what primary care physicians can do. Cleve Clin J Med. 2012;79(5):313-320.

43. Hosain GM, Sanderson M, Du XL, Chan W, Strom SS. Racial/ethnic differences in predictors of PSA screening in a tri-ethnic population. Cent Eur J Public Health. 2011;19(1):30-34.

44. Kyle C, Ewing T, Wu XC, Mercante D, Lifsey D, Meunier $\mathrm{C}$, Jefferson L, et al. Statewide analysis of serum prostate specific antigen levels in Louisiana men without prostate cancer. J La State Med Soc. 2004;156(6):319-323.

45. Vijayakumar S, Winter K, Sause W, Gallagher MJ, Michalski J, Roach M, Porter A, et al. Prostate-specific antigen levels are higher in African-American than in white patients in a multicenter registration study: results of RTOG 94-12. Int J Radiat Oncol Biol Phys. 1998;40(1):17-25.

46. Okobia MN, Zmuda JM, Ferrell RE, Patrick AL, Bunker $\mathrm{CH}$. Chromosome 8q24 variants are associated with prostate cancer risk in a high risk population of African ancestry. Prostate. 2011;71(10):1054-1063.

47. Haiman CA, Chen GK, Blot WJ, Strom SS, Berndt SI, Kittles RA, Rybicki BA, et al. Characterizing genetic risk 
at known prostate cancer susceptibility loci in African Americans. PLoS Genet. 2011;7(5):e1001387.

48. Freedman ML, Haiman CA, Patterson N, McDonald GJ, Tandon A, Waliszewska A, Penney K, et al. Admixture mapping identifies $8 \mathrm{q} 24$ as a prostate cancer risk locus in African-American men. Proc Natl Acad Sci U S A. 2006;103(38):14068-14073.

49. Chang BL, Isaacs SD, Wiley KE, Gillanders EM, Zheng SL, Meyers DA, Walsh PC, et al. Genome-wide screen for prostate cancer susceptibility genes in men with clinically significant disease. Prostate. 2005;64(4):356-361.

50. Robbins CM, Hooker S, Kittles RA, Carpten JD. EphB2 SNPs and sporadic prostate cancer risk in African American men. PLoS One. 2011;6(5):e19494.

51. Hatcher D, Daniels G, Osman I, Lee P. Molecular mechanisms involving prostate cancer racial disparity. Am J Transl Res. 2009;1(3):235-248.

52. Gallagher RP, Fleshner N. Prostate cancer: 3. Individual risk factors. CMAJ. 1998;159(7):807-813.

53. Carroll PR, Grossfeld GD, editors. Prostate cancer. Hamilton, London: Decker Inc.; 2002.

54. Ferris-i-Tortajada J, Garcia-i-Castell J, Berbel-Tornero O, Ortega-Garcia JA. [Constitutional risk factors in prostate cancer]. Actas Urol Esp. 2011;35(5):282-288.

55. Sridhar G, Masho SW, Adera T, Ramakrishnan V, Roberts JD. Association between family history of prostate cancer. JMH. 2010;7:45-54.

56. Chen H, Griffin AR, Wu YQ, Tomsho LP, Zuhlke KA, Lange EM, Gruber SB, et al. RNASEL mutations in hereditary prostate cancer. J Med Genet. 2003;40(3):e21.

57. Malathi K, Dong B, Gale M, Jr., Silverman RH. Small self-RNA generated by RNase L amplifies antiviral innate immunity. Nature. 2007;448(7155):816-819.

58. Zhou A, Paranjape J, Brown TL, Nie H, Naik S, Dong B, Chang A, et al. Interferon action and apoptosis are defective in mice devoid of 2',5'-oligoadenylate-dependent RNase L. EMBO J. 1997;16(21):6355-6363.

59. Urisman A, Molinaro RJ, Fischer N, Plummer SJ, Casey G, Klein EA, Malathi K, et al. Identification of a novel Gammaretrovirus in prostate tumors of patients homozygous for R462Q RNASEL variant. PLoS Pathog. 2006;2(3):e25.

60. Eeles RA, Kote-Jarai Z, Giles GG, Olama AA, Guy M, Jugurnauth SK, Mulholland S, et al. Multiple newly identified loci associated with prostate cancer susceptibility. Nat Genet. 2008;40(3):316-321.

61. Schlaberg R, Choe DJ, Brown KR, Thaker HM, Singh IR. $\mathrm{XMRV}$ is present in malignant prostatic epithelium and is associated with prostate cancer, especially high-grade tumors. Proc Natl Acad Sci U S A. 2009;106(38):1635116356.

62. Camp NJ, Tavtigian SV. Meta-analysis of associations of the Ser217Leu and Ala541Thr variants in ELAC2 (HPC2) and prostate cancer. Am J Hum Genet. 2002;71(6):14751478.

63. Noda D, Itoh S, Watanabe $\mathrm{Y}$, Inamitsu $\mathrm{M}$, Dennler $\mathrm{S}$, Itoh $\mathrm{F}$, Koike $\mathrm{S}$, et al. ELAC2, a putative prostate cancer susceptibility gene product, potentiates TGF-beta/ Smad-induced growth arrest of prostate cells. Oncogene.
2006;25(41):5591-5600.

64. Xu J, Zheng SL, Komiya A, Mychaleckyj JC, Isaacs $\mathrm{SD}, \mathrm{Hu}$ JJ, Sterling D, et al. Germline mutations and sequence variants of the macrophage scavenger receptor 1 gene are associated with prostate cancer risk. Nat Genet. 2002;32(2):321-325.

65. Maier C, Vesovic Z, Bachmann N, Herkommer K, Braun AK, Surowy HM, Assum G, et al. Germline mutations of the MSR1 gene in prostate cancer families from Germany. Hum Mutat. 2006;27(1):98-102.

66. Wang L, McDonnell SK, Cunningham JM, Hebbring S, Jacobsen SJ, Cerhan JR, Slager SL, et al. No association of germline alteration of MSR 1 with prostate cancer risk. Nat Genet. 2003;35(2):128-129.

67. Erkko H, Xia B, Nikkila J, Schleutker J, Syrjakoski K, Mannermaa A, Kallioniemi A, et al. A recurrent mutation in PALB2 in Finnish cancer families. Nature. 2007;446(7133):316-319.

68. Gallagher DJ, Gaudet MM, Pal P, Kirchhoff T, Balistreri L, Vora K, Bhatia J, et al. Germline BRCA mutations denote a clinicopathologic subset of prostate cancer. Clin Cancer Res. 2010;16(7):2115-2121.

69. Xu J, Meyers D, Freije D, Isaacs S, Wiley K, Nusskern D, Ewing C, et al. Evidence for a prostate cancer susceptibility locus on the $\mathrm{X}$ chromosome. Nat Genet. 1998;20(2):175-179.

70. Bergthorsson JT, Johannesdottir G, Arason A, Benediktsdottir KR, Agnarsson BA, Bailey-Wilson JE, Gillanders $\mathrm{E}$, et al. Analysis of HPC1, HPCX, and PCaP in Icelandic hereditary prostate cancer. Hum Genet. 2000;107(4):372375.

71. Stanford JL, FitzGerald LM, McDonnell SK, Carlson EE, McIntosh LM, Deutsch K, Hood L, et al. Dense genomewide SNP linkage scan in 301 hereditary prostate cancer families identifies multiple regions with suggestive evidence for linkage. Hum Mol Genet. 2009;18(10):18391848.

72. Hsing AW, Tsao L, Devesa SS. International trends and patterns of prostate cancer incidence and mortality. Int J Cancer. 2000;85(1):60-67.

73. Howell MA. Factor analysis of international cancer mortality data and per capita food consumption. Br J Cancer. 1974;29(4):328-336.

74. Armstrong B, Doll R. Environmental factors and cancer incidence and mortality in different countries, with special reference to dietary practices. Int J Cancer. 1975;15(4):617-631.

75. Aronson WJ, Barnard RJ, Freedland SJ, Henning S, Elashoff D, Jardack PM, Cohen P, et al. Growth inhibitory effect of low fat diet on prostate cancer cells: results of a prospective, randomized dietary intervention trial in men with prostate cancer. J Urol. 2010;183(1):345-350.

76. Venkateswaran V, Klotz LH. Diet and prostate cancer: mechanisms of action and implications for chemoprevention. Nat Rev Urol. 2010;7(8):442-453.

77. Pauwels EK. The protective effect of the Mediterranean diet: focus on cancer and cardiovascular risk. Med Princ Pract. 2011;20(2):103-111.

78. Fleshner N, Zlotta AR. Prostate cancer prevention: past, 
present, and future. Cancer. 2007;110(9):1889-1899.

79. Hamalainen E, Adlercreutz H, Puska P, Pietinen P. Diet and serum sex hormones in healthy men. J Steroid Biochem. 1984;20(1):459-464.

80. Hamalainen EK, Adlercreutz H, Puska P, Pietinen P. Decrease of serum total and free testosterone during a lowfat high-fibre diet. J Steroid Biochem. 1983;18(3):369370.

81. Rosenthal MB, Barnard RJ, Rose DP, Inkeles S, Hall J, Pritikin N. Effects of a high-complex-carbohydrate, lowfat, low-cholesterol diet on levels of serum lipids and estradiol. Am J Med. 1985;78(1):23-27.

82. Lloyd JC, Masko EM, Wu C, Keenan MM, Pilla DM, Aronson WJ, Chi JT, et al. Fish oil slows prostate cancer xenograft growth relative to other dietary fats and is associated with decreased mitochondrial and insulin pathway gene expression. Prostate Cancer Prostatic Dis. 2013;16(4):285-291.

83. Berquin IM, Min $\mathrm{Y}, \mathrm{Wu} \mathrm{R}, \mathrm{Wu} \mathrm{J}$, Perry $\mathrm{D}$, Cline JM, Thomas MJ, et al. Modulation of prostate cancer genetic risk by omega- 3 and omega- 6 fatty acids. J Clin Invest. 2007;117(7):1866-1875.

84. Gibson TM, Ferrucci LM, Tangrea JA, Schatzkin A. Epidemiological and clinical studies of nutrition. Semin Oncol. 2010;37(3):282-296.

85. Rohrmann S, Platz EA, Kavanaugh CJ, Thuita L, Hoffman SC, Helzlsouer KJ. Meat and dairy consumption and subsequent risk of prostate cancer in a US cohort study. Cancer Causes Control. 2007;18(1):41-50.

86. Major JM, Cross AJ, Watters JL, Hollenbeck AR, Graubard BI, Sinha R. Patterns of meat intake and risk of prostate cancer among African-Americans in a large prospective study. Cancer Causes Control. 2011;22(12):1691-1698.

87. Sinha R, Knize MG, Salmon CP, Brown ED, Rhodes D, Felton JS, Levander OA, et al. Heterocyclic amine content of pork products cooked by different methods and to varying degrees of doneness. Food Chem Toxicol. 1998;36(4):289-297.

88. Kazerouni N, Sinha R, Hsu CH, Greenberg A, Rothman N. Analysis of 200 food items for benzo[a]pyrene and estimation of its intake in an epidemiologic study. Food Chem Toxicol. 2001;39(5):423-436.

89. Sinha R, Park Y, Graubard BI, Leitzmann MF, Hollenbeck A, Schatzkin A, Cross AJ. Meat and meat-related compounds and risk of prostate cancer in a large prospective cohort study in the United States. Am J Epidemiol. 2009;170(9):1165-1177.

90. Tappel A. Heme of consumed red meat can act as a catalyst of oxidative damage and could initiate colon, breast and prostate cancers, heart disease and other diseases. Med Hypotheses. 2007;68(3):562-564.

91. Gao X, LaValley MP, Tucker KL. Prospective studies of dairy product and calcium intakes and prostate cancer risk: a meta-analysis. J Natl Cancer Inst. 2005;97(23):17681777.

92. Allen NE, Key TJ, Appleby PN, Travis RC, Roddam AW, Tjonneland A, Johnsen NF, et al. Animal foods, protein, calcium and prostate cancer risk: the European Prospective Investigation into Cancer and Nutrition. Br J Cancer.
2008;98(9):1574-1581.

93. Park Y, Mitrou PN, Kipnis V, Hollenbeck A, Schatzkin A, Leitzmann MF. Calcium, dairy foods, and risk of incident and fatal prostate cancer: the NIH-AARP Diet and Health Study. Am J Epidemiol. 2007;166(11):1270-1279.

94. Koh KA, Sesso HD, Paffenbarger RS, Jr., Lee IM. Dairy products, calcium and prostate cancer risk. Br J Cancer. 2006;95(11):1582-1585.

95. Gupta S. Prostate cancer chemoprevention: current status and future prospects. Toxicol Appl Pharmacol. 2007;224(3):369-376.

96. Wilson KM, Shui IM, Mucci LA, Giovannucci E. Calcium and phosphorus intake and prostate cancer risk: a 24-y follow-up study. Am J Clin Nutr. 2015;101(1):173-183.

97. Singh SV, Srivastava SK, Choi S, Lew KL, Antosiewicz J, Xiao D, Zeng Y, et al. Sulforaphane-induced cell death in human prostate cancer cells is initiated by reactive oxygen species. J Biol Chem. 2005;280(20):19911-19924.

98. Joseph MA, Moysich KB, Freudenheim JL, Shields PG, Bowman ED, Zhang Y, Marshall JR, et al. Cruciferous vegetables, genetic polymorphisms in glutathione Stransferases $\mathrm{M} 1$ and $\mathrm{T} 1$, and prostate cancer risk. Nutr Cancer. 2004;50(2):206-213.

99. Giovannucci E, Rimm EB, Liu Y, Stampfer MJ, Willett WC. A prospective study of cruciferous vegetables and prostate cancer. Cancer Epidemiol Biomarkers Prev. 2003;12(12):1403-1409.

100. Hsing AW, Comstock GW, Abbey H, Polk BF. Serologic precursors of cancer. Retinol, carotenoids, and tocopherol and risk of prostate cancer. J Natl Cancer Inst. 1990;82(11):941-946.

101. Key TJ, Allen N, Appleby P, Overvad K, Tjonneland A, Miller A, Boeing $\mathrm{H}$, et al. Fruits and vegetables and prostate cancer: no association among 1104 cases in a prospective study of 130544 men in the European Prospective Investigation into Cancer and Nutrition (EPIC). Int J Cancer. 2004;109(1):119-124.

102. Stram DO, Hankin JH, Wilkens LR, Park S, Henderson BE, Nomura AM, Pike MC, et al. Prostate cancer incidence and intake of fruits, vegetables and related micronutrients: the multiethnic cohort study* (United States). Cancer Causes Control. 2006;17(9):1193-1207.

103. Fujiki H, Suganuma M, Okabe S, Sueoka N, Komori A, Sueoka E, Kozu T, et al. Cancer inhibition by green tea. Mutat Res. 1998;402(1-2):307-310.

104. Inoue M, Tajima K, Hirose K, Hamajima N, Takezaki T, Kuroishi T, Tominaga S. Tea and coffee consumption and the risk of digestive tract cancers: data from a comparative case-referent study in Japan. Cancer Causes Control. 1998;9(2):209-216.

105. Ji BT, Chow WH, Hsing AW, McLaughlin JK, Dai Q, Gao YT, Blot WJ, et al. Green tea consumption and the risk of pancreatic and colorectal cancers. Int J Cancer. 1997;70(3):255-258.

106. Nakachi K, Suemasu K, Suga K, Takeo T, Imai K, Higashi Y. Influence of drinking green tea on breast cancer malignancy among Japanese patients. Jpn J Cancer Res. 1998;89(3):254-261.

107. Beltz LA, Bayer DK, Moss AL, Simet IM. Mechanisms 
of cancer prevention by green and black tea polyphenols. Anticancer Agents Med Chem. 2006;6(5):389-406.

108. Handayani R, Rice L, Cui Y, Medrano TA, Samedi VG, Baker HV, Szabo NJ, et al. Soy isoflavones alter expression of genes associated with cancer progression, including interleukin-8, in androgen-independent PC-3 human prostate cancer cells. J Nutr. 2006;136(1):75-82.

109. Fotsis T, Pepper M, Adlercreutz H, Hase T, Montesano $\mathrm{R}$, Schweigerer L. Genistein, a dietary ingested isoflavonoid, inhibits cell proliferation and in vitro angiogenesis. J Nutr. 1995;125(3 Suppl):790S-797S.

110. Zhang L, Li L, Jiao M, Wu D, Wu K, Li X, Zhu G, et al. Genistein inhibits the stemness properties of prostate cancer cells through targeting Hedgehog-Gli1 pathway. Cancer Lett. 2012;323(1):48-57.

111. Zhu BH, Zhan WH, Li ZR, Wang Z, He YL, Peng JS, Cai $\mathrm{SR}$, et al. -)-Epigallocatechin-3-gallate inhibits growth of gastric cancer by reducing VEGF production and angiogenesis. World J Gastroenterol. 2007;13(8):1162-1169.

112. Hastak K, Agarwal MK, Mukhtar H, Agarwal ML. Ablation of either p21 or Bax prevents p53-dependent apoptosis induced by green tea polyphenol epigallocatechin3-gallate. FASEB J. 2005;19(7):789-791.

113. Sartor L, Pezzato E, Dona M, Dell'Aica I, Calabrese F, Morini M, Albini A, et al. Prostate carcinoma and green tea: (-)epigallocatechin-3-gallate inhibits inflammationtriggered MMP-2 activation and invasion in murine TRAMP model. Int J Cancer. 2004;112(5):823-829.

114. Adhami VM, Siddiqui IA, Ahmad N, Gupta S, Mukhtar H. Oral consumption of green tea polyphenols inhibits insulin-like growth factor-I-induced signaling in an autochthonous mouse model of prostate cancer. Cancer Res. 2004;64(23):8715-8722.

115. van Breemen RB, Pajkovic N. Multitargeted therapy of cancer by lycopene. Cancer Lett. 2008;269(2):339-351.

116. Guns ES, Cowell SP. Drug Insight: lycopene in the prevention and treatment of prostate cancer. Nat Clin Pract Urol. 2005;2(1):38-43.

117. Muzandu K, El Bohi K, Shaban Z, Ishizuka M, Kazusaka A, Fujita S. Lycopene and beta-carotene ameliorate catechol estrogen-mediated DNA damage. Jpn J Vet Res. 2005;52(4):173-184.

118. Park YO, Hwang ES, Moon TW. The effect of lycopene on cell growth and oxidative DNA damage of Hep3B human hepatoma cells. Biofactors. 2005;23(3):129-139.

119. Erdman JW, Jr., Ford NA, Lindshield BL. Are the health attributes of lycopene related to its antioxidant function? Arch Biochem Biophys. 2009;483(2):229-235.

120. Liu X, Allen JD, Arnold JT, Blackman MR. Lycopene inhibits IGF-I signal transduction and growth in normal prostate epithelial cells by decreasing DHT-modulated IGF-I production in co-cultured reactive stromal cells. Carcinogenesis. 2008;29(4):816-823.

121. Giovannucci E, Liu Y, Platz EA, Stampfer MJ, Willett WC. Risk factors for prostate cancer incidence and progression in the health professionals follow-up study. Int J Cancer. 2007;121(7):1571-1578.

122. Venkateswaran V, Klotz LH, Ramani M, Sugar LM, Jacob LE, Nam RK, Fleshner NE. A combination of micro- nutrients is beneficial in reducing the incidence of prostate cancer and increasing survival in the Lady transgenic model. Cancer Prev Res (Phila). 2009;2(5):473-483.

123. Schwenke C, Ubrig B, Thurmann P, Eggersmann C, Roth $\mathrm{S}$. Lycopene for advanced hormone refractory prostate cancer: a prospective, open phase II pilot study. J Urol. 2009;181(3):1098-1103.

124. Kirsh VA, Mayne ST, Peters U, Chatterjee N, Leitzmann MF, Dixon LB, Urban DA, et al. A prospective study of lycopene and tomato product intake and risk of prostate cancer. Cancer Epidemiol Biomarkers Prev. 2006;15(1):92-98.

125. Peters U, Leitzmann MF, Chatterjee N, Wang Y, Albanes D, Gelmann EP, Friesen MD, et al. Serum lycopene, other carotenoids, and prostate cancer risk: a nested casecontrol study in the prostate, lung, colorectal, and ovarian cancer screening trial. Cancer Epidemiol Biomarkers Prev. 2007;16(5):962-968.

126. Mullins JK, Loeb S. Environmental exposures and prostate cancer. Urol Oncol. 2012;30(2):216-219.

127. Grant WB, Peiris AN. Differences in vitamin D status may account for unexplained disparities in cancer survival rates between African and white Americans. Dermatoendocrinol. 2012;4(2):85-94.

128. Schwartz GG, Hulka BS. Is vitamin D deficiency a risk factor for prostate cancer? (Hypothesis). Anticancer Res. 1990;10(5A):1307-1311.

129. Barnett CM, Beer TM. Prostate cancer and vitamin D: what does the evidence really suggest? Urol Clin North Am. 2011;38(3):333-342.

130. Racial geographic, genetic and body habitus effects on vitamin D metabolism [press release]. San Diego: Academic Press. 1997.

131. Chen TC, Holick MF. Vitamin D and prostate cancer prevention and treatment. Trends Endocrinol Metab. $2003 ; 14(9): 423-430$.

132. Miller GJ. Vitamin D and prostate cancer: biologic interactions and clinical potentials. Cancer Metastasis Rev. 1998;17(4):353-360.

133. Blutt SE, Polek TC, Stewart LV, Kattan MW, Weigel NL. A calcitriol analogue, EB1089, inhibits the growth of LNCaP tumors in nude mice. Cancer Res. 2000;60(4):779782.

134. Bhatia V, Saini MK, Shen X, Bi LX, Qiu S, Weigel NL, Falzon M. EB1089 inhibits the parathyroid hormonerelated protein-enhanced bone metastasis and xenograft growth of human prostate cancer cells. Mol Cancer Ther. 2009;8(7):1787-1798.

135. Datta M, Schwartz GG. Calcium and vitamin D supplementation during androgen deprivation therapy for prostate cancer: a critical review. Oncologist. 2012;17(9):1171-1179.

136. Gross C, Stamey T, Hancock S, Feldman D. Treatment of early recurrent prostate cancer with 1,25-dihydroxyvitamin D3 (calcitriol). J Urol. 1998;159(6):2035-2039; discussion 2039-2040.

137. Osborn JL, Schwartz GG, Smith DC, Bahnson R, Day R, Trump DL. Phase II trial of oral 1,25-dihydroxyvitamin $\mathrm{D}$ (calcitriol) in hormone refractory prostate cancer. Urol 
Oncol. 1995;1(5):195-198.

138. el Attar TM, Lin HS. Effect of vitamin $C$ and vitamin $E$ on prostaglandin synthesis by fibroblasts and squamous carcinoma cells. Prostaglandins Leukot Essent Fatty Acids. 1992;47(4):253-257.

139. Alpha-Tocopherol BCCPSG. The effect of vitamin $\mathrm{E}$ and beta carotene on the incidence of lung cancer and other cancers in male smokers. N Engl J Med. 1994;330(15):1029-1035.

140. Lippman SM, Klein EA, Goodman PJ, Lucia MS, Thompson IM, Ford LG, Parnes HL, et al. Effect of selenium and vitamin $\mathrm{E}$ on risk of prostate cancer and other cancers: the Selenium and Vitamin E Cancer Prevention Trial (SELECT). JAMA. 2009;301(1):39-51.

141. Helzlsouer KJ, Huang HY, Alberg AJ, Hoffman S, Burke A, Norkus EP, Morris JS, et al. Association between alphatocopherol, gamma-tocopherol, selenium, and subsequent prostate cancer. J Natl Cancer Inst. 2000;92(24):20182023.

142. Yoshizawa K, Willett WC, Morris SJ, Stampfer MJ, Spiegelman D, Rimm EB, Giovannucci E. Study of prediagnostic selenium level in toenails and the risk of advanced prostate cancer. J Natl Cancer Inst. 1998;90(16):12191224.

143. Duffield-Lillico AJ, Dalkin BL, Reid ME, Turnbull BW, Slate EH, Jacobs ET, Marshall JR, et al. Selenium supplementation, baseline plasma selenium status and incidence of prostate cancer: an analysis of the complete treatment period of the Nutritional Prevention of Cancer Trial. BJU Int. 2003;91(7):608-612.

144. Morris JD, Pramanik R, Zhang X, Carey AM, Ragavan N, Martin FL, Muir GH. Selenium- or quercetin-induced retardation of DNA synthesis in primary prostate cells occurs in the presence of a concomitant reduction in androgen-receptor activity. Cancer Lett. 2006;239(1):111-122.

145. Venkateswaran V, Klotz LH, Fleshner NE. Selenium modulation of cell proliferation and cell cycle biomarkers in human prostate carcinoma cell lines. Cancer Res. 2002;62(9):2540-2545.

146. Venkateswaran V. Selenium and prostate cancer: biological pathways and biochemical nuances. Cancer Ther. 2006;4:73-80.

147. Hu H, Jiang C, Ip C, Rustum YM, Lu J. Methylseleninic acid potentiates apoptosis induced by chemotherapeutic drugs in androgen-independent prostate cancer cells. Clin Cancer Res. 2005;11(6):2379-2388.

148. Chan JM, Oh WK, Xie W, Regan MM, Stampfer MJ, King IB, Abe M, et al. Plasma selenium, manganese superoxide dismutase, and intermediate- or high-risk prostate cancer. J Clin Oncol. 2009;27(22):3577-3583.

149. Blount BC, Mack MM, Wehr CM, MacGregor JT, Hiatt RA, Wang G, Wickramasinghe SN, et al. Folate deficiency causes uracil misincorporation into human DNA and chromosome breakage: implications for cancer and neuronal damage. Proc Natl Acad Sci U S A. 1997;94(7):3290-3295.

150. Petersen LF, Brockton NT, Bakkar A, Liu S, Wen J, Weljie AM, Bismar TA. Elevated physiological levels of folic acid can increase in vitro growth and invasiveness of prostate cancer cells. BJU Int. 2012;109(5):788-795.

151. Bistulfi G, Foster BA, Karasik E, Gillard B, Miecznikowski J, Dhiman VK, Smiraglia DJ. Dietary folate deficiency blocks prostate cancer progression in the TRAMP model. Cancer Prev Res (Phila). 2011;4(11):1825-1834.

152. de Vogel S, Meyer K, Fredriksen A, Ulvik A, Ueland PM, Nygard O, Vollset SE, et al. Serum folate and vitamin B12 concentrations in relation to prostate cancer risk-a Norwegian population-based nested case-control study of 3000 cases and 3000 controls within the JANUS cohort. Int J Epidemiol. 2013;42(1):201-210.

153. Guo S, Jiang X, Chen X, Chen L, Li X, Jia Y. The protective effect of methylenetetrahydrofolate reductase C677T polymorphism against prostate cancer risk: Evidence from 23 case-control studies. Gene. 2015;565(1):90-95.

154. Tomaszewski JJ, Cummings JL, Parwani AV, Dhir R, Mason JB, Nelson JB, Bacich DJ, et al. Increased cancer cell proliferation in prostate cancer patients with high levels of serum folate. Prostate. 2011;71(12):1287-1293.

155. Collin SM, Metcalfe C, Refsum H, Lewis SJ, Zuccolo L, Smith GD, Chen L, et al. Circulating folate, vitamin B12, homocysteine, vitamin B12 transport proteins, and risk of prostate cancer: a case-control study, systematic review, and meta-analysis. Cancer Epidemiol Biomarkers Prev. 2010;19(6):1632-1642.

156. Tomaszewski JJ, Richman EL, Sadetsky N, O'Keefe DS, Carroll PR, Davies BJ, Chan JM. Impact of folate intake on prostate cancer recurrence following definitive therapy: data from CaPSURE. J Urol. 2014;191(4):971-976.

157. Kasperzyk JL, Fall K, Mucci LA, Hakansson N, Wolk A, Johansson JE, Andersson SO, et al. One-carbon metabolism-related nutrients and prostate cancer survival. Am J Clin Nutr. 2009;90(3):561-569.

158. Hiatt RA, Armstrong MA, Klatsky AL, Sidney S. Alcohol consumption, smoking, and other risk factors and prostate cancer in a large health plan cohort in California (United States). Cancer Causes Control. 1994;5(1):66-72.

159. Rizos C, Papassava M, Golias C, Charalabopoulos K. Alcohol consumption and prostate cancer: a mini review. Exp Oncol. 2010;32(2):66-70.

160. Schmidt W, De Lint J. Causes of death of alcoholics. Q J Stud Alcohol. 1972;33(1):171-185.

161. Pell S, D'Alonzo CA. A five-year mortality study of alcoholics. J Occup Med. 1973;15(2):120-125.

162. Hirayama T. Life-style and cancer: from epidemiological evidence to public behavior change to mortality reduction of target cancers. J Natl Cancer Inst Monogr. 1992;12:6574.

163. Hsing AW, McLaughlin JK, Schuman LM, Bjelke E, Gridley G, Wacholder S, Chien HT, et al. Diet, tobacco use, and fatal prostate cancer: results from the Lutheran Brotherhood Cohort Study. Cancer Res. 1990;50(21):6836-6840.

164. Adami HO, McLaughlin JK, Hsing AW, Wolk A, Ekbom A, Holmberg L, Persson I. Alcoholism and cancer risk: a population-based cohort study. Cancer Causes Control. 1992;3(5):419-425.

165. Middleton Fillmore K, Chikritzhs T, Stockwell T, Bostrom A, Pascal R. Alcohol use and prostate cancer: a meta-analysis. Mol Nutr Food Res. 2009;53(2):240-255. 
166. Rota M, Scotti L, Turati F, Tramacere I, Islami F, Bellocco R, Negri E, et al. Alcohol consumption and prostate cancer risk: a meta-analysis of the dose-risk relation. Eur J Cancer Prev. 2012;21(4):350-359.

167. Tunnicliffe JM, Shearer J. Coffee, glucose homeostasis, and insulin resistance: physiological mechanisms and mediators. Appl Physiol Nutr Metab. 2008;33(6):12901300 .

168. Wilson KM, Kasperzyk JL, Rider JR, Kenfield S, van Dam RM, Stampfer MJ, Giovannucci E, et al. Coffee consumption and prostate cancer risk and progression in the Health Professionals Follow-up Study. J Natl Cancer Inst. 2011;103(11):876-884.

169. Ma J, Li H, Giovannucci E, Mucci L, Qiu W, Nguyen PL, Gaziano JM, et al. Prediagnostic body-mass index, plasma C-peptide concentration, and prostate cancer-specific mortality in men with prostate cancer: a long-term survival analysis. Lancet Oncol. 2008;9(11):1039-1047.

170. Hammarsten J, Hogstedt B. Hyperinsulinaemia: a prospective risk factor for lethal clinical prostate cancer. Eur J Cancer. 2005;41(18):2887-2895.

171. Lehrer S, Diamond EJ, Stagger S, Stone NN, Stock RG. Serum insulin level, disease stage, prostate specific antigen (PSA) and Gleason score in prostate cancer. Br J Cancer. 2002;87(7):726-728.

172. Stattin P, Bylund A, Rinaldi S, Biessy C, Dechaud H, Stenman UH, Egevad L, et al. Plasma insulin-like growth factor-I, insulin-like growth factor-binding proteins, and prostate cancer risk: a prospective study. J Natl Cancer Inst. 2000;92(23):1910-1917.

173. Stocks T, Lukanova A, Rinaldi S, Biessy C, Dossus L, Lindahl B, Hallmans G, et al. Insulin resistance is inversely related to prostate cancer: a prospective study in Northern Sweden. Int J Cancer. 2007;120(12):26782686.

174. De Marzo AM, Platz EA, Sutcliffe S, Xu J, Gronberg H, Drake CG, Nakai Y, et al. Inflammation in prostate carcinogenesis. Nat Rev Cancer. 2007;7(4):256-269.

175. Demark-Wahnefried W, Moyad MA. Dietary intervention in the management of prostate cancer. Curr Opin Urol. 2007;17(3):168-174.

176. Greenwald P. Clinical trials in cancer prevention: current results and perspectives for the future. J Nutr. 2004;134(12 Suppl):3507S-3512S.

177. Freedland SJ, Aronson WJ. Obesity and prostate cancer. Urology. 2005;65(3):433-439.

178. Mcbride RB. Obesity and aggressive prostate cancer bias and biomarkers. Columbia University, 2012.

179. Kaaks R, Stattin P. Obesity, endogenous hormone metabolism, and prostate cancer risk: a conundrum of "highs" and "lows". Cancer Prev Res (Phila). 2010;3(3):259-262.

180. Fuentes E, Fuentes F, Vilahur G, Badimon L, Palomo I. Mechanisms of chronic state of inflammation as mediators that link obese adipose tissue and metabolic syndrome. Mediators Inflamm. 2013;2013:136584.

181. Allott EH, Masko EM, Freedland SJ. Obesity and prostate cancer: weighing the evidence. Eur Urol. 2013;63(5):800809.

182. Parekh N, Lin Y, Dipaola RS, Marcella S, Lu-Yao G.
Obesity and prostate cancer detection: insights from three national surveys. Am J Med. 2010;123(9):829-835.

183. Banez LL, Hamilton RJ, Partin AW, Vollmer RT, Sun L, Rodriguez C, Wang Y, et al. Obesity-related plasma hemodilution and PSA concentration among men with prostate cancer. JAMA. 2007;298(19):2275-2280.

184. Keogh JW, MacLeod RD. Body composition, physical fitness, functional performance, quality of life, and fatigue benefits of exercise for prostate cancer patients: a systematic review. J Pain Symptom Manage. 2012;43(1):96110.

185. (IARC) IAfRoC. Tobacco smoke and involuntary smoking. IARC monographs on the evaluation of carcinogenic risks in human 83. Lyon, France: IARC Press; 2004.

186. Huncharek M, Haddock KS, Reid R, Kupelnick B. Smoking as a risk factor for prostate cancer: a meta-analysis of 24 prospective cohort studies. Am J Public Health. 2010;100(4):693-701.

187. Nock NL, Liu X, Cicek MS, Li L, Macarie F, Rybicki BA, Plummer SJ, et al. Polymorphisms in polycyclic aromatic hydrocarbon metabolism and conjugation genes, interactions with smoking and prostate cancer risk. Cancer Epidemiol Biomarkers Prev. 2006;15(4):756-761.

188. Li J, Thompson T, Joseph DA, Master VA. Association between smoking status, and free, total and percent free prostate specific antigen. J Urol. 2012;187(4):1228-1233.

189. Platz EA, Giovannucci E. Prostate Cancer. In: Schottenfeld D, Fraumeni JF, Jr., editors. Cancer epidemiology and prevention. Oxford: Oxford University Press; 2006. p. $1128-1150$.

190. Cerhan JR, Torner JC, Lynch CF, Rubenstein LM, Lemke $\mathrm{JH}$, Cohen MB, Lubaroff DM, et al. Association of smoking, body mass, and physical activity with risk of prostate cancer in the Iowa 65+ Rural Health Study (United States). Cancer Causes Control. 1997;8(2):229-238.

191. Giovannucci E, Rimm EB, Ascherio A, Colditz GA, Spiegelman D, Stampfer MJ, Willett WC. Smoking and risk of total and fatal prostate cancer in United States health professionals. Cancer Epidemiol Biomarkers Prev. 1999;8(4 Pt 1):277-282.

192. Huggins C, Hodges CV. Studies on prostatic cancer. I. The effect of castration, of estrogen and of androgen injection on serum phosphatases in metastatic carcinoma of the prostate. 1941. J Urol. 2002;167(2 Pt 2):948-951; discussion 952.

193. Kyprianou N, English HF, Isaacs JT. Programmed cell death during regression of PC-82 human prostate cancer following androgen ablation. Cancer Res. 1990;50(12):3748-3753.

194. Webber MM, Bello D, Quader S. Immortalized and tumorigenic adult human prostatic epithelial cell lines: characteristics and applications. Part I. Cell markers and immortalized nontumorigenic cell lines. Prostate. 1996;29(6):386-394.

195. Bladou F, Vessella RL, Buhler KR, Ellis WJ, True LD, Lange PH. Cell proliferation and apoptosis during prostatic tumor xenograft involution and regrowth after castration. Int J Cancer. 1996;67(6):785-790.

196. Ahmad I, Sansom OJ, Leung HY. Advances in mouse 
models of prostate cancer. Expert Rev Mol Med. 2008;10:e16.

197. Rove KO, Crawford ED. Traditional androgen ablation approaches to advanced prostate cancer: new insights. Can J Urol. 2014;21(2 Supp 1):14-21.

198. Michaud JE, Billups KL, Partin AW. Testosterone and prostate cancer: an evidence-based review of pathogenesis and oncologic risk. Ther Adv Urol. 2015;7(6):378387.

199. Chang BL, Zheng SL, Hawkins GA, Isaacs SD, Wiley KE, Turner A, Carpten JD, et al. Joint effect of HSD3B1 and HSD3B2 genes is associated with hereditary and sporadic prostate cancer susceptibility. Cancer Res. 2002;62(6):1784-1789.

200. Kraft P, Pharoah P, Chanock SJ, Albanes D, Kolonel LN, Hayes RB, Altshuler D, et al. Genetic variation in the HSD17B1 gene and risk of prostate cancer. PLoS Genet. 2005;1(5):e68.

201. Margiotti K, Kim E, Pearce CL, Spera E, Novelli G, Reichardt JK. Association of the G289S single nucleotide polymorphism in the HSD17B3 gene with prostate cancer in Italian men. Prostate. 2002;53(1):65-68.

202. Suzuki M, Muto S, Hara K, Ozeki T, Yamada Y, Kadowaki T, Tomita K, et al. Single-nucleotide polymorphisms in the 17beta-hydroxysteroid dehydrogenase genes might predict the risk of side-effects of estramustine phosphate sodium in prostate cancer patients. Int J Urol. 2005;12(2):166-172.

203. Setlur SR, Chen CX, Hossain RR, Ha JS, Van Doren VE, Stenzel B, Steiner E, et al. Genetic variation of genes involved in dihydrotestosterone metabolism and the risk of prostate cancer. Cancer Epidemiol Biomarkers Prev. 2010;19(1):229-239.

204. Lindstrom S, Wiklund F, Adami HO, Balter KA, Adolfsson J, Gronberg H. Germ-line genetic variation in the key androgen-regulating genes androgen receptor, cytochrome P450, and steroid-5-alpha-reductase type 2 is important for prostate cancer development. Cancer Res. 2006;66(22):11077-11083.

205. Chang BL, Zheng SL, Isaacs SD, Turner AR, Bleecker ER, Walsh PC, Meyers DA, et al. Evaluation of SRD5A2 sequence variants in susceptibility to hereditary and sporadic prostate cancer. Prostate. 2003;56(1):37-44.

206. Loukola A, Chadha M, Penn SG, Rank D, Conti DV, Thompson D, Cicek M, et al. Comprehensive evaluation of the association between prostate cancer and genotypes/haplotypes in CYP17A1, CYP3A4, and SRD5A2. Eur J Hum Genet. 2004;12(4):321-332.

207. Sarma AV, Dunn RL, Lange LA, Ray A, Wang Y, Lange EM, Cooney KA. Genetic polymorphisms in CYP17, CYP3A4, CYP19A1, SRD5A2, IGF-1, and IGFBP-3 and prostate cancer risk in African-American men: the Flint Men's Health Study. Prostate. 2008;68(3):296-305.

208. Cramer SD, Sun J, Zheng SL, Xu J, Peehl DM. Association of prostate-specific antigen promoter genotype with clinical and histopathologic features of prostate cancer. Cancer Epidemiol Biomarkers Prev. 2008;17(9):24512457.

209. Nam RK, Zhang WW, Klotz LH, Trachtenberg J, Jewett
MA, Sweet J, Toi A, et al. Variants of the hK2 protein gene (KLK2) are associated with serum hK2 levels and predict the presence of prostate cancer at biopsy. Clin Cancer Res. 2006;12(21):6452-6458.

210. Klein RJ, Hallden C, Cronin AM, Ploner A, Wiklund F, Bjartell AS, Stattin P, et al. Blood biomarker levels to aid discovery of cancer-related single-nucleotide polymorphisms: kallikreins and prostate cancer. Cancer Prev Res (Phila). 2010;3(5):611-619.

211. Beuten J, Gelfond JA, Franke JL, Weldon KS, Crandall AC, Johnson-Pais TL, Thompson IM, et al. Single and multigenic analysis of the association between variants in 12 steroid hormone metabolism genes and risk of prostate cancer. Cancer Epidemiol Biomarkers Prev. 2009;18(6):1869-1880.

212. Chang BL, Cramer SD, Wiklund F, Isaacs SD, Stevens VL, Sun J, Smith S, et al. Fine mapping association study and functional analysis implicate a SNP in MSMB at $10 \mathrm{q} 11$ as a causal variant for prostate cancer risk. Hum Mol Genet. 2009;18(7):1368-1375.

213. Lou H, Yeager M, Li H, Bosquet JG, Hayes RB, Orr N, $\mathrm{Yu} \mathrm{K}$, et al. Fine mapping and functional analysis of a common variant in MSMB on chromosome 10q11.2 associated with prostate cancer susceptibility. Proc Natl Acad Sci U S A. 2009;106(19):7933-7938.

214. Hernandez J, Balic I, Johnson-Pais TL, Higgins BA, Torkko KC, Thompson IM, Leach RJ. Association between an estrogen receptor alpha gene polymorphism and the risk of prostate cancer in black men. J Urol. 2006;175(2):523527.

215. Chen YC, Kraft P, Bretsky P, Ketkar S, Hunter DJ, Albanes $\mathrm{D}$, Altshuler D, et al. Sequence variants of estrogen receptor beta and risk of prostate cancer in the National Cancer Institute Breast and Prostate Cancer Cohort Consortium. Cancer Epidemiol Biomarkers Prev. 2007;16(10):19731981.

216. Thellenberg-Karlsson C, Lindstrom S, Malmer B, Wiklund F, Augustsson-Balter K, Adami HO, Stattin $\mathrm{P}$, et al. Estrogen receptor beta polymorphism is associated with prostate cancer risk. Clin Cancer Res. 2006;12(6):1936-1941.

217. Rajah TT, Pento JT. The mutagenic potential of antiestrogens at the HPRT locus in V79 cells. Res Commun Mol Pathol Pharmacol. 1995;89(1):85-92.

218. Akanni A, Abul-Hajj YJ. Estrogen-nucleic acid adducts: reaction of 3,4-estrone-o-quinone radical anion with deoxyribonucleosides. Chem Res Toxicol. 1997;10(7):760766.

219. Lambe M, Wigertz A, Garmo H, Walldius G, Jungner I, Hammar N. Impaired glucose metabolism and diabetes and the risk of breast, endometrial, and ovarian cancer. Cancer Causes Control. 2011;22(8):1163-1171.

220. Bhindi B, Locke J, Alibhai SMH, Kulkarni GS, Margel DS, Hamilton RJ, Finelli A, et al. Dissecting the association between metabolic syndrome and prostate cancer risk: analysis of a large clinical cohort. Eur Urol. 2015;67(1):64-70.

221. Arthur R, Moller H, Garmo H, Holmberg L, Stattin P, Malmstrom H, Lambe M, et al. Association between 
baseline serum glucose, triglycerides and total cholesterol, and prostate cancer risk categories. Cancer Med. 2016;5(6):1307-1318.

222. Sharma N, Sood S, Kaushik GG, Ali Z. Risk of prostate cancer and its correlation with different biochemical parameters in nondiabetic men. Int J Res Med Sci. 2013;1:476-481.

223. Kang J, Chen MH, Zhang Y, Moran BJ, Dosoretz DE, Katin MJ, Braccioforte MH, et al. Type of diabetes mellitus and the odds of Gleason score 8 to 10 prostate cancer. Int J Radiat Oncol Biol Phys. 2012;82(3):e463-467.

224. Tsilidis KK, Allen NE, Appleby PN, Rohrmann S, Nothlings U, Arriola L, Gunter MJ, et al. Diabetes mellitus and risk of prostate cancer in the European prospective investigation into cancer and nutrition. Int $\mathrm{J}$ Cancer. 2015;136(2):372-381.

225. Calton BA, Chang SC, Wright ME, Kipnis V, Lawson $\mathrm{K}$, Thompson FE, Subar AF, et al. History of diabetes mellitus and subsequent prostate cancer risk in the NIHAARP Diet and Health Study. Cancer Causes Control. 2007;18(5):493-503.

226. Fall K, Garmo H, Gudbjornsdottir S, Stattin P, Zethelius B. Diabetes mellitus and prostate cancer risk; a nationwide case-control study within PCBaSe Sweden. Cancer Epidemiol Biomarkers Prev. 2013;22(6):1102-1109.

227. Warburg O. On the origin of cancer cells. Science. 1956;123(3191):309-314.

228. Wang L, Xiong H, Wu F, Zhang Y, Wang J, Zhao L, Guo X, et al. Hexokinase 2-mediated Warburg effect is required for PTEN- and p53-deficiency-driven prostate cancer growth. Cell Rep. 2014;8(5):1461-1474.

229. Chandler JD, Williams ED, Slavin JL, Best JD, Rogers S. Expression and localization of GLUT1 and GLUT12 in prostate carcinoma. Cancer. 2003;97(8):2035-2042.

230. Giovannucci E, Michaud D. The role of obesity and related metabolic disturbances in cancers of the colon, prostate, and pancreas. Gastroenterology. 2007;132(6):22082225.

231. Mangal P, Mittal S, Kachhawa K, Agrawal D, Rath B, Kumar S. Analysis of the clinical profile in patients with plasmodium falciparum malaria and its association with parasite density. J Glob Infect Dis. 2017;9(2):60-65.

232. Venkateswaran V, Haddad AQ, Fleshner NE, Fan R, Sugar LM, Nam R, Klotz LH, et al. Association of diet-induced hyperinsulinemia with accelerated growth of prostate cancer (LNCaP) xenografts. J Natl Cancer Inst. 2007;99(23):1793-1800.

233. Abe R, Yamagishi S. AGE-RAGE system and carcinogenesis. Curr Pharm Des. 2008;14(10):940-945.

234. Gennigens C, Menetrier-Caux C, Droz JP. Insulin-Like Growth Factor (IGF) family and prostate cancer. Crit Rev Oncol Hematol. 2006;58(2):124-145.

235. Pollak M. Insulin and insulin-like growth factor signalling in neoplasia. Nat Rev Cancer. 2008;8(12):915-928.

236. Chan JM, Stampfer MJ, Giovannucci E, Gann PH, Ma J, Wilkinson P, Hennekens $\mathrm{CH}$, et al. Plasma insulin-like growth factor-I and prostate cancer risk: a prospective study. Science. 1998;279(5350):563-566.

237. Ryan CJ, Haqq CM, Simko J, Nonaka DF, Chan JM,
Weinberg V, Small EJ, et al. Expression of insulin-like growth factor-1 receptor in local and metastatic prostate cancer. Urol Oncol. 2007;25(2):134-140.

238. Price AJ, Allen NE, Appleby PN, Crowe FL, Travis RC, Tipper SJ, Overvad K, et al. Insulin-like growth factor-I concentration and risk of prostate cancer: results from the European Prospective Investigation into Cancer and Nutrition. Cancer Epidemiol Biomarkers Prev. 2012;21(9):1531-1541.

239. Liao Y, Abel U, Grobholz R, Hermani A, Trojan L, Angel $\mathrm{P}$, Mayer D. Up-regulation of insulin-like growth factor axis components in human primary prostate cancer correlates with tumor grade. Hum Pathol. 2005;36(11):11861196.

240. Chott A, Sun Z, Morganstern D, Pan J, Li T, Susani M, Mosberger I, et al. Tyrosine kinases expressed in vivo by human prostate cancer bone marrow metastases and loss of the type 1 insulin-like growth factor receptor. Am J Pathol. 1999;155(4):1271-1279.

241. Cox ME, Gleave ME, Zakikhani M, Bell RH, Piura E, Vickers E, Cunningham M, et al. Insulin receptor expression by human prostate cancers. Prostate. 2009;69(1):3340.

242. Sutcliffe S, Pontari MA. Inflammation and infection in the etiology of prostate cancer. Prostate Cancer. 2 ed: Academic Press; 2016. p. 13-20.

243. Gurel B, Lucia MS, Thompson IM, Jr., Goodman PJ, Tangen CM, Kristal AR, Parnes HL, et al. Chronic inflammation in benign prostate tissue is associated with highgrade prostate cancer in the placebo arm of the prostate cancer prevention trial. Cancer Epidemiol Biomarkers Prev. 2014;23(5):847-856.

244. Galdiero MR, Bonavita E, Barajon I, Garlanda C, Mantovani A, Jaillon S. Tumor associated macrophages and neutrophils in cancer. Immunobiology. 2013;218(11):1402-1410.

245. Schatteman PH, Hoekx L, Wyndaele JJ, Jeuris W, Van Marck E. Inflammation in prostate biopsies of men without prostatic malignancy or clinical prostatitis: correlation with total serum PSA and PSA density. Eur Urol. 2000;37(4):404-412.

246. Stallone G, Cormio L, Netti GS, Infante B, Selvaggio O, Fino GD, Ranieri E, et al. Pentraxin 3: a novel biomarker for predicting progression from prostatic inflammation to prostate cancer. Cancer Res. 2014;74(16):4230-4238.

247. De Marzo AM, Meeker AK, Zha S, Luo J, Nakayama M, Platz EA, Isaacs WB, et al. Human prostate cancer precursors and pathobiology. Urology. 2003;62(5 Suppl 1):55-62.

248. Danforth KN, Hayes RB, Rodriguez C, Yu K, Sakoda LC, Huang WY, Chen BE, et al. Polymorphic variants in PTGS2 and prostate cancer risk: results from two large nested case-control studies. Carcinogenesis. 2008;29(3):568-572.

249. Fernandez P, de Beer PM, van der Merwe L, Heyns CF. COX-2 promoter polymorphisms and the association with prostate cancer risk in South African men. Carcinogenesis. 2008;29(12):2347-2350.

250. Zabaleta J, Su LJ, Lin HY, Sierra RA, Hall MC, Sartor 
AO, Clark PE, et al. Cytokine genetic polymorphisms and prostate cancer aggressiveness. Carcinogenesis. 2009;30(8):1358-1362.

251. Bao S, Yang W, Zhou S, Ye Z. Relationship between single nucleotide polymorphisms in $-174 \mathrm{G} / \mathrm{C}$ and $-634 \mathrm{C} / \mathrm{G}$ promoter region of interleukin-6 and prostate cancer. J Huazhong Univ Sci Technolog Med Sci. 2008;28(6):693-696.

252. Pierce BL, Biggs ML, DeCambre M, Reiner AP, Li C, Fitzpatrick A, Carlson CS, et al. C-reactive protein, interleukin-6, and prostate cancer risk in men aged 65 years and older. Cancer Causes Control. 2009;20(7):11931203.

253. Wang MH, Helzlsouer KJ, Smith MW, Hoffman-Bolton JA, Clipp SL, Grinberg V, De Marzo AM, et al. Association of IL10 and other immune response- and obesityrelated genes with prostate cancer in CLUE II. Prostate. 2009;69(8):874-885.

254. Danforth KN, Rodriguez C, Hayes RB, Sakoda LC, Huang WY, Yu K, Calle EE, et al. TNF polymorphisms and prostate cancer risk. Prostate. 2008;68(4):400-407.

255. Chen YC, Giovannucci E, Lazarus R, Kraft P, Ketkar S, Hunter DJ. Sequence variants of Toll-like receptor 4 and susceptibility to prostate cancer. Cancer Res. 2005;65(24):11771-11778.

256. Song J, Kim DY, Kim CS, Kim HJ, Lee DH, Lee HM, Ko W, et al. The association between Toll-like receptor 4 (TLR4) polymorphisms and the risk of prostate cancer in Korean men. Cancer Genet Cytogenet. 2009;190(2):8892.

257. Stark JR, Wiklund F, Gronberg H, Schumacher F, Sinnott JA, Stampfer MJ, Mucci LA, et al. Toll-like receptor signaling pathway variants and prostate cancer mortality. Cancer Epidemiol Biomarkers Prev. 2009;18(6):18591863.

258. Roberts RO, Lieber MM, Rhodes T, Girman CJ, Bostwick DG, Jacobsen SJ. Prevalence of a physician-assigned diagnosis of prostatitis: the Olmsted County Study of Urinary Symptoms and Health Status Among Men. Urology. 1998;51(4):578-584.

259. Krieger JN, Riley DE, Cheah PY, Liong ML, Yuen KH. Epidemiology of prostatitis: new evidence for a worldwide problem. World J Urol. 2003;21(2):70-74.

260. Lu H, Ouyang W, Huang C. Inflammation, a key event in cancer development. Mol Cancer Res. 2006;4(4):221233.

261. Dennis LK, Lynch CF, Torner JC. Epidemiologic association between prostatitis and prostate cancer. Urology. 2002;60(1):78-83.

262. Jiang J, Li J, Yunxia Z, Zhu H, Liu J, Pumill C. The role of prostatitis in prostate cancer: meta-analysis. PLoS One. 2013;8(12):e85179.

263. Kirby RS, Lowe D, Bultitude MI, Shuttleworth KE. Intraprostatic urinary reflux: an aetiological factor in abacterial prostatitis. Br J Urol. 1982;54(6):729-731.

264. Shinohara DB, Vaghasia AM, Yu SH, Mak TN, Bruggemann H, Nelson WG, De Marzo AM, et al. A mouse model of chronic prostatic inflammation using a human prostate cancer-derived isolate of Propionibacterium ac- nes. Prostate. 2013;73(9):1007-1015.

265. Elkahwaji JE, Zhong W, Hopkins WJ, Bushman W. Chronic bacterial infection and inflammation incite reactive hyperplasia in a mouse model of chronic prostatitis. Prostate. 2007;67(1):14-21.

266. Pelouze PS. Gonorrhea in the male and female: a book for practitioners. Philadelphia: W.B. Saunders Company; 1935.

267. Poletti F, Medici MC, Alinovi A, Menozzi MG, Sacchini P, Stagni G, Toni M, et al. Isolation of Chlamydia trachomatis from the prostatic cells in patients affected by nonacute abacterial prostatitis. J Urol. 1985;134(4):691693.

268. Hayes RB, Pottern LM, Strickler H, Rabkin C, Pope V, Swanson GM, Greenberg RS, et al. Sexual behaviour, STDs and risks for prostate cancer. Br J Cancer. 2000;82(3):718-725.

269. Taylor ML, Mainous AG, 3rd, Wells BJ. Prostate cancer and sexually transmitted diseases: a meta-analysis. Fam Med. 2005;37(7):506-512.

270. Dunne EF, Nielson CM, Stone KM, Markowitz LE, Giuliano AR. Prevalence of HPV infection among men: A systematic review of the literature. J Infect Dis. 2006;194(8):1044-1057.

271. Looker KJ, Garnett GP, Schmid GP. An estimate of the global prevalence and incidence of herpes simplex virus type 2 infection. Bull W H O. 2008;86(10):805-812.

272. Bosch FX, Burchell AN, Schiffman M, Giuliano AR, de Sanjose S, Bruni L, Tortolero-Luna G, et al. Epidemiology and natural history of human papillomavirus infections and type-specific implications in cervical neoplasia. Vaccine. 2008;26(Suppl 10):K1-16.

273. Chaturvedi AK. Beyond cervical cancer: burden of other HPV-related cancers among men and women. J Adolesc Health. 2010;46(4 Suppl):S20-26.

274. Ravich A, Ravich RA. Prophylaxis of cancer of the prostate, penis, and cervix by circumcision. N Y State J Med. 1951;51(12):1519-1520.

275. Sutcliffe S. Sexually transmitted infections and risk of prostate cancer: review of historical and emerging hypotheses. Future Oncol. 2010;6(8):1289-1311.

276. Cuzick J. Human papillomavirus infection of the prostate. Cancer Surv. 1995;23:91-95.

277. Dillner J, Knekt P, Boman J, Lehtinen M, Af Geijersstam V, Sapp M, Schiller J, et al. Sero-epidemiological association between human-papillomavirus infection and risk of prostate cancer. Int J Cancer. 1998;75(4):564-567.

278. Al Moustafa AE. Involvement of human papillomavirus infections in prostate cancer progression. Med Hypotheses. 2008;71(2):209-211.

279. Strickler HD, Burk R, Shah K, Viscidi R, Jackson A, Pizza G, Bertoni F, et al. A multifaceted study of human papillomavirus and prostate carcinoma. Cancer. 1998;82(6):1118-1125.

280. Lin Y, Mao Q, Zheng X, Yang K, Chen H, Zhou C, Xie L. Human papillomavirus 16 or 18 infection and prostate cancer risk: a meta-analysis. Ir J Med Sci. 2011;180(2):497503.

281. Tsang SH, Peisch SF, Rowan B, Markt SC, Gonzalez- 
Feliciano AG, Sutcliffe S, Platz EA, et al. Association between Trichomonas vaginalis and prostate cancer mortality. Int J Cancer. 2019;144(10):2377-2380.

282. Walsh PC, Madden JD, Harrod MJ, Goldstein JL, MacDonald PC, Wilson JD. Familial incomplete male pseudohermaphroditism, type 2. Decreased dihydrotestosterone formation in pseudovaginal perineoscrotal hypospadias. N Engl J Med. 1974;291(18):944-949.

283. Petrow V, Padilla GM, Mukherji S, Marts SA. Endocrine dependence of prostatic cancer upon dihydrotestosterone and not upon testosterone. J Pharm Pharmacol. 1984;36(5):352-353.

284. McConnell JD, Roehrborn CG, Bautista OM, Andriole GL, Jr., Dixon CM, Kusek JW, Lepor H, et al. The longterm effect of doxazosin, finasteride, and combination therapy on the clinical progression of benign prostatic hyperplasia. N Engl J Med. 2003;349(25):2387-2398.

285. Roehrborn CG, Barkin J, Siami P, Tubaro A, Wilson TH, Morrill BB, Gagnier RP. Clinical outcomes after combined therapy with dutasteride plus tamsulosin or either monotherapy in men with benign prostatic hyperplasia $(\mathrm{BPH})$ by baseline characteristics: 4-year results from the randomized, double-blind Combination of Avodart and Tamsulosin (CombAT) trial. BJU Int. 2011;107(6):946-954.

286. Dorsam J, Altwein J. 5alpha-Reductase inhibitor treatment of prostatic diseases: background and practical implications. Prostate Cancer Prostatic Dis. 2009;12(2):130136.

287. Thompson IM, Goodman PJ, Tangen CM, Lucia MS, Miller GJ, Ford LG, Lieber MM, et al. The influence of finasteride on the development of prostate cancer. N Engl J Med. 2003;349(3):215-224.

288. Andriole GL, Bostwick DG, Brawley OW, Gomella LG, Marberger M, Montorsi F, Pettaway CA, et al. Effect of dutasteride on the risk of prostate cancer. N Engl J Med. 2010;362(13):1192-1202.

289. Fleshner N, Lucia MS, Melich K, Nandy IM, Black L, Rittmaster RS. Effect of dutasteride on prostate cancer progression and cancer diagnosis on rebiopsy in the REDEEM surveillance study. [abstract]. J Clin Oncol. 2011;29(7_suppl):2-2.

290. Bowers LW, Maximo IX, Brenner AJ, Beeram M, Hursting SD, Price RS, Tekmal RR, et al. NSAID use reduces breast cancer recurrence in overweight and obese women: role of prostaglandin-aromatase interactions. Cancer Res. 2014;74(16):4446-4457.

291. Jafari S, Etminan M, Afshar K. Nonsteroidal anti-inflammatory drugs and prostate cancer: a systematic review of the literature and meta-analysis. Can Urol Assoc J. 2009;3(4):323-330.

292. Roberts RO, Jacobson DJ, Girman CJ, Rhodes T, Lieber MM, Jacobsen SJ. A population-based study of daily nonsteroidal anti-inflammatory drug use and prostate cancer. Mayo Clin Proc. 2002;77(3):219-225.

293. Leitzmann MF, Stampfer MJ, Ma J, Chan JM, Colditz GA, Willett WC, Giovannucci E. Aspirin use in relation to risk of prostate cancer. Cancer Epidemiol Biomarkers Prev. 2002;11(10 Pt 1):1108-1111.

294. Salinas CA, Kwon EM, FitzGerald LM, Feng Z, Nelson
PS, Ostrander EA, Peters U, et al. Use of aspirin and other nonsteroidal antiinflammatory medications in relation to prostate cancer risk. Am J Epidemiol. 2010;172(5):578590 .

295. Habel LA, Zhao W, Stanford JL. Daily aspirin use and prostate cancer risk in a large, multiracial cohort in the US. Cancer Causes Control. 2002;13(5):427-434.

296. Hamilton RJ, Goldberg KC, Platz EA, Freedland SJ. The influence of statin medications on prostate-specific antigen levels. J Natl Cancer Inst. 2008;100(21):1511-1518.

297. Chang SL, Harshman LC, Presti JC, Jr. Impact of common medications on serum total prostate-specific antigen levels: analysis of the National Health and Nutrition Examination Survey. J Clin Oncol. 2010;28(25):3951-3957.

298. Bonovas S, Filioussi K, Sitaras NM. Statin use and the risk of prostate cancer: A metaanalysis of 6 randomized clinical trials and 13 observational studies. Int J Cancer. 2008;123(4):899-904.

299. Gutt R, Tonlaar N, Kunnavakkam R, Karrison T, Weichselbaum RR, Liauw SL. Statin use and risk of prostate cancer recurrence in men treated with radiation therapy. J Clin Oncol. 2010;28(16):2653-2659.

300. Hamilton RJ, Banez LL, Aronson WJ, Terris MK, Platz EA, Kane CJ, Presti JC, Jr., et al. Statin medication use and the risk of biochemical recurrence after radical prostatectomy: results from the Shared Equal Access Regional Cancer Hospital (SEARCH) Database. Cancer. 2010;116(14):3389-3398.

301. Ku JH, Jeong CW, Park YH, Cho MC, Kwak C, Kim HH. Relationship of statins to clinical presentation and biochemical outcomes after radical prostatectomy in Korean patients. Prostate Cancer Prostatic Dis. 2011;14(1):63-68.

302. (PDQ) NCICT. Statin therapy versus placebo prior to prostatectomy. In: Development VOoRa, editor. 2017.

303. (PDQ) NCICT. Phase II study of atorvastatin calcium and celecoxib in patients with hormone-dependent prostatespecific antigen progression after local therapy for prostate cancer. 2018.

304. Ansbaugh N, Shannon J, Mori M, Farris PE, Garzotto M. Agent Orange as a risk factor for high-grade prostate cancer. Cancer. 2013;119(13):2399-2404.

305. Shah SR, Terris MK. Editorial comment on: Agent Orange exposure, Vietnam War veterans, and the risk of prostate cancer. Cancer. 2008;113(9):2382-2384.

306. Hammond B, Katzenellenbogen BS, Krauthammer N, McConnell J. Estrogenic activity of the insecticide chlordecone (Kepone) and interaction with uterine estrogen receptors. Proc Natl Acad Sci U S A. 1979;76(12):66416645.

307. Eroschenko VP. Estrogenic activity of the insecticide chlordecone in the reproductive tract of birds and mammals. J Toxicol Environ Health. 1981;8(5-6):731-742.

308. Sirica AE, Wilkerson CS, Wu LL, Fitzgerald R, Blanke RV, Guzelian PS. Evaluation of chlordecone in a twostage model of hepatocarcinogenesis: a significant sex difference in the hepatocellular carcinoma incidence. Carcinogenesis. 1989;10(6):1047-1054.

309. Alavanja MC, Samanic C, Dosemeci M, Lubin J, Tarone $\mathrm{R}$, Lynch CF, Knott C, et al. Use of agricultural pesticides 
and prostate cancer risk in the Agricultural Health Study cohort. Am J Epidemiol. 2003;157(9):800-814.

310. Mahajan R, Bonner MR, Hoppin JA, Alavanja MC. Phorate exposure and incidence of cancer in the agricultural health study. Environ Health Perspect. 2006;114(8):12051209.

311. Lynch SM, Mahajan R, Beane Freeman LE, Hoppin JA, Alavanja MC. Cancer incidence among pesticide applicators exposed to butylate in the Agricultural Health Study (AHS). Environ Res. 2009;109(7):860-868.

312. Christensen CH, Platz EA, Andreotti G, Blair A, Hoppin JA, Koutros S, Lynch CF, et al. Coumaphos exposure and incident cancer among male participants in the Agricultural Health Study (AHS). Environ Health Perspect. 2010;118(1):92-96.

313. Molowa DT, Shayne AG, Guzelian PS. Purification and characterization of chlordecone reductase from human liver. J Biol Chem. 1986;261(27):12624-12627.

314. Kume T, Iwasa H, Shiraishi H, Yokoi T, Nagashima K, Otsuka M, Terada T, et al. Characterization of a novel variant (S145C/L311V) of 3alpha-hydroxysteroid/dihydrodiol dehydrogenase in human liver. Pharmacogenetics. 1999;9(6):763-771.

315. Rubin BS. Bisphenol A: an endocrine disruptor with widespread exposure and multiple effects. J Steroid Biochem Mol Biol. 2011;127(1-2):27-34.

316. Sungur S, Koroglu M, Ozkan A. Determination of bisphenol a migrating from canned food and beverages in markets. Food Chem. 2014;142:87-91.

317. Geens T, Aerts D, Berthot C, Bourguignon JP, Goeyens L, Lecomte P, Maghuin-Rogister G, et al. A review of dietary and non-dietary exposure to bisphenol-A. Food Chem Toxicol. 2012;50(10):3725-3740.

318. Acevedo N, Davis B, Schaeberle CM, Sonnenschein C, Soto AM. Perinatally administered bisphenol a as a potential mammary gland carcinogen in rats. Environ Health Perspect. 2013;121(9):1040-1046.

319. Nomura SO, Harnack L, Robien K. Estimating bisphenol A exposure levels using a questionnaire targeting known sources of exposure. Public Health Nutr. 2016;19(4):593606.

320. Tarapore P, Ying J, Ouyang B, Burke B, Bracken B, Ho SM. Exposure to bisphenol A correlates with early-onset prostate cancer and promotes centrosome amplification and anchorage-independent growth in vitro. PLoS One. 2014;9(3):e90332.

321. Prins GS, Hu WY, Shi GB, Hu DP, Majumdar S, Li G, Huang K, et al. Bisphenol A promotes human prostate stem-progenitor cell self-renewal and increases in vivo carcinogenesis in human prostate epithelium. Endocrinology. 2014;155(3):805-817.

322. Ho SM, Rao R, To S, Schoch E, Tarapore P. Bisphenol A and its analogues disrupt centrosome cycle and microtubule dynamics in prostate cancer. Endocr Relat Cancer. 2017;24(2):83-96.

323. Tse LA, Lee PMY, Ho WM, Lam AT, Lee MK, Ng SSM, $\mathrm{He} \mathrm{Y}$, et al. Bisphenol A and other environmental risk factors for prostate cancer in Hong Kong. Environ Int. 2017;107:1-7.
324. Shirai T, Asamoto M, Takahashi S, Imaida K. Diet and prostate cancer. Toxicology. 2002;181-182:89-94.

325. Norrish AE, Ferguson LR, Knize MG, Felton JS, Sharpe SJ, Jackson RT. Heterocyclic amine content of cooked meat and risk of prostate cancer. J Natl Cancer Inst. 1999;91(23):2038-2044.

326. Stott-Miller M, Neuhouser ML, Stanford JL. Consumption of deep-fried foods and risk of prostate cancer. Prostate. 2013;73(9):960-969.

327. Holt SK, Salinas CA, Stanford JL. Vasectomy and the risk of prostate cancer. J Urol. 2008;180(6):2565-2567; discussion 2567-2568.

328. Cox B, Sneyd MJ, Paul C, Delahunt B, Skegg DC. Vasectomy and risk of prostate cancer. JAMA. 2002;287(23):31103115.

329. Schwingl PJ, Meirik O, Kapp N, Farley TM, on behalf of the HRP Multicenter Study of Prostate Cancer and Vasectomy. Prostate cancer and vasectomy: a hospital-based case-control study in China, Nepal and the Republic of Korea. Contraception. 2009;79(5):363-368.

330. Leitzmann MF, Platz EA, Stampfer MJ, Willett WC, Giovannucci E. Ejaculation frequency and subsequent risk of prostate cancer. JAMA. 2004;291(13):1578-1586.

331. Rider JR, Wilson KM, Sinnott JA, Kelly RS, Mucci LA, Giovannucci EL. Ejaculation Frequency and Risk of Prostate Cancer: Updated Results with an Additional Decade of Follow-up. Eur Urol. 2016;70(6):974-982.

332. Papa NP, MacInnis RJ, English DR, Bolton D, Davis ID, Lawrentschuk N, Millar JL, et al. Ejaculatory frequency and the risk of aggressive prostate cancer: Findings from a case-control study. Urol Oncol. 2017;35(8):530.e7-530. e13.

333. Isaacs JT. Prostatic structure and function in relation to the etiology of prostatic cancer. Prostate. 1983;4(4):351366.

334. Costello LC, Franklin RB. The clinical relevance of the metabolism of prostate cancer; zinc and tumor suppression: connecting the dots. Mol Cancer. 2006;5:17.

335. Svatek RS, Karam JA, Rogers TE, Shulman MJ, Margulis V, Benaim EA. Intraluminal crystalloids are highly associated with prostatic adenocarcinoma on concurrent biopsy specimens. Prostate Cancer Prostatic Dis. 2007;10(3):279-282.

336. Del Rosario AD, Bui HX, Abdulla M, Ross JS. Sulfurrich prostatic intraluminal crystalloids: a surgical pathologic and electron probe x-ray microanalytic study. Hum Pathol. 1993;24(11):1159-1167.

337. Newman HF, Reiss H, Northup JD. Physical basis of emission, ejaculation, and orgasm in the male. Urology. $1982 ; 19(4): 341-350$.

338. Myles P, Evans S, Lophatananon A, Dimitropoulou P, Easton D, Key T, Pocock R, et al. Diagnostic radiation procedures and risk of prostate cancer. Br J Cancer. 2008;98(11):1852-1856.

339. Stark T, Livas L, Kyprianou N. Inflammation in prostate cancer progression and therapeutic targeting. Transl Androl Urol. 2015;4(4):455-463.

340. Raghow S, Hooshdaran MZ, Katiyar S, Steiner MS. Toremifene prevents prostate cancer in the transgenic 
adenocarcinoma of mouse prostate model. Cancer Res. 2002;62(5):1370-1376.

341. Bresalier RS, Sandler RS, Quan H, Bolognese JA, Oxenius B, Horgan K, Lines C, et al. Cardiovascular events associated with rofecoxib in a colorectal adenoma chemoprevention trial. N Engl J Med. 2005;352(11):1092-1102.

342. Price D, Stein B, Sieber P, Tutrone R, Bailen J, Goluboff $\mathrm{E}$, Burzon D, et al. Toremifene for the prevention of prostate cancer in men with high grade prostatic intraepithelial neoplasia: results of a double-blind, placebo controlled, phase IIB clinical trial. J Urol. 2006;176(3):965-970; dis- cussion 970-961.

343. Taneja SS, Morton R, Barnette G, Sieber P, Hancock ML, Steiner M. Prostate cancer diagnosis among men with isolated high-grade intraepithelial neoplasia enrolled onto a 3-year prospective phase III clinical trial of oral toremifene. J Clin Oncol. 2013;31(5):523-529.

344. Jorgensen JT. Drug-diagnostics co-development in oncology. Front Oncol. 2014;4:208.

345. Olsen D, Jorgensen JT. Companion diagnostics for targeted cancer drugs - clinical and regulatory aspects. Front Oncol. 2014;4:105. 